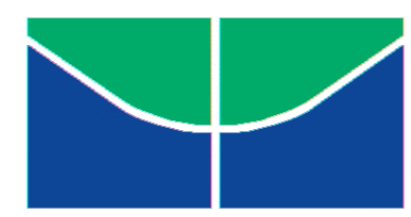

UNIVERSIDADE DE BRASÍLIA

INSTITUTO DE QUÍMICA

PROGRAMA DE PÓS-GRADUAÇÃO EM TECNOLOGIAS QUíMICA E BIOLÓGICA

\title{
USO DE CATALISADORES PLATíNICOS NA HIDROGENAÇÃO DE BIODIESEL
}

\author{
Yuri Henrique de Oliveira Falcão \\ Orientador: Prof. Dr. Paulo Anselmo Ziani Suarez
}

Brasília-DF

Junho de 2016 


\section{UNIVERSIDADE DE BRASÍLIA \\ INSTITUTO DE QUÍMICA}

PROGRAMA DE PÓS-GRADUAÇÃO EM TECNOLOGIAS QUÍMICA E BIOLÓGICA

\section{USO DE CATALISADORES PLATÍNICOS NA HIDROGENAÇÃO DE BIODIESEL}

Dissertação apresentada ao Programa de PósGraduação em Tecnologias Química e Biológica do Instituto de Química da Universidade de Brasília, como requisito parcial à obtenção do título de Mestre.

Yuri Henrique de Oliveira Falcão

Orientador: Prof. Dr. Paulo Anselmo Ziani Suarez

\section{Brasília-DF}

Junho de 2016 


\section{FOLHA DE APROVAÇÃO}

Comunicamos a aprovação da Defesa de Dissertação de Mestrado do (a) aluno (a) Yuri Henrique de Oliveira Falcão, matrícula no 14/0106707, intitulada "Uso de catalisadores platínicos na hidrogenação de Biodiesel", apresentada no (a) Auditório do CDT da Universidade de Brasília (UnB) em 28 de junho de 2016.

Prof. Dr. Paulo Anselmo Ziani Suarez
Presidente de Banca (IQ/UnB)

Prof. Dr. Fábio Moreira da Silva

Membro Titular (IQ/UnB)

Prof. Dr. Melquizedeque Bento Alves

Membro Titular (ANA)

Prof. Dr. José Joaquín Linares León

Membro Suplente (IQ/UnB)

Em 28 de junho de 2016. 


\section{Agradecimentos}

Gostaria de agradecer primeiramente à minha super mega Mãe e à minha amada futura esposa, Brenda Roberta, pois elas me incentivaram a fazer tudo isso e devo este trabalho a elas duas. Além disto, sem a existência delas este trabalho e o meu empenho não existiriam.

Agradeço também a todos da família, não citarei todos os nomes pois não tem espaço pra tanta gente querida e especial (incluindo Kaká, Hélio, David, Vinícius, Henrique e famílias, que são da família do coração), por estarem presentes durante todo este tempo e me proporcionarem ótimas lembranças, momentos, ensinamentos, tudo de bom. Obrigado por me darem a honra de ser desta enorme família!

Ao meu Pai, por toda ajuda, por todos os momentos, viagens, conversas, etc.

Ao tio Flávio, por todos os ensinamentos, pelo exemplo, por estar presente no meu desenvolvimento, sempre ajudando, e sempre com o famoso churrasco!

Ao grande professor e grande amigo Paulo Suarez, por todos os sermões, ensinamentos, ajuda, boas conversas, amizade e acima de tudo pela ótima orientação desde o $2^{0}$ semestre da minha graduação.

Ao excelentíssimo amigo, o grande David!!! Por ser meu coorientador de coração, mesmo não podendo ser oficialmente e por ser um grande amigo e exemplo de pessoa.

À toda galera do LMC que conheci durante esses vários anos. São muitos nomes e muitos amigos, obrigado pelas boas conversas de tarde, pelos cafés do Mateus Montenegro, pelas ajudas, dicas e amizades.

Aos professores Juliano Prauchner, Marcelo Rodrigues, Fábio Moreira, Juliana Rodrigues, Andressa, Julio Lemos (um grande exemplo de professor e profissional), e Grace Ghesti, por toda ajuda, conselhos e ensinamentos durantes estes anos na UnB.

Ao professor Marcos Jacinto, e todo pessoal envolvido na pesquisa dos catalisadores platínicos, pela ajudas, trabalhos, parcerias, ensinamentos, fornecimento de materiais e por todo companheirismo.

A todos os amigos que conheci durante o tempo na universidade, pelas boas e "polidas" festas, conversas, ensinamentos e tudo mais!

Ao pessoal da UnB toda, à Inó e ao Leo um agradecimento especial! Ao pessoal da pós-graduação e demais professores, por toda a gentileza e ajuda durante esses anos. 
"Quando alcançarmos o nosso horizonte de eventos e vermos que, assim como nós somos um grão de areia dentro de um universo, o nosso universo é apenas um grão de areia dentro de um indefinido e indescritivel conjunto de outros universos singulares, cada um com seus incalculáveis paralelos, entenderemos que cada um de nós é tão importante quanto insignificante e que apenas a curiosidade e a inquietação nos faz crescer e a nossa honra, humildade e amor pelo próximo nos faz continuar grandes. $\mathcal{E}$ talvez um dia conseguiremos sair desta casca e veremos o céu de um modo nunca antes visto."

Y. H. O. Falcão. 


\section{Resumo}

Hoje há uma crescente demanda de biodiesel no Brasil, atrelado a isso há também uma forte demanda de combustíveis ecológicos que diminuam a emissão de carbono na atmosfera. Frente à inserção de biodiesel nos combustíveis há problemas relacionados a este, sendo um dos principais a sua estabilidade à oxidação, que normalmente é sanada por meio de aditivos antioxidantes que aumentam o custo deste combustível. Uma possível alternativa para o melhoramento das propriedades do biodiesel sem o emprego de aditivos é a hidrogenação seletiva. Neste trabalho foi estuda a hidrogenação de biodiesel de soja com catalisadores platínicos em suportes do tipo core-shell magnéticos, que facilitam a recuperação destes por meio de campos magnéticos e diminuem custos e perdas de material, os catalisadores são: $\mathrm{Fe}_{3} \mathrm{O}_{4} @ \mathrm{mSiO}_{2} @ \mathrm{Pt}$ e $\mathrm{Fe}_{3} \mathrm{O}_{4} @ \mathrm{mSiO} \mathrm{O}_{2} @ \mathrm{Pt} / \mathrm{Pd}$. Os catalisadores foram reutilizados 3 e 4 vezes, respectivamente, sem perda considerável de atividade. Para o catalisador $\mathrm{Fe}_{3} \mathrm{O}_{4} @ \mathrm{mSiO} \mathrm{O}_{2} @ \mathrm{Pt}$ a mistura de produtos hidrogenados continha um acréscimo de mais de $21 \%$ no teor de oleato de metila, gerando um produto com maior estabilidade oxidativa quando comparado com o biodiesel, isto sem comprometer consideravelmente as propriedades de viscosidade e ponto de fusão, também foi notada uma seletividade alta comparável à de trabalhos de hidrogenação com o emprego de solventes iônicos. Testes com solventes iônicos mostraram que estes influenciaram negativamente a reação, diminuindo a velocidade desta ou até impedindo que a reação acontecesse. Neste trabalho foi mostrada a aplicação de catalisadores magnéticos platínicos para o melhoramento do biodiesel por hidrogenação. 


\begin{abstract}
Nowadays there is an increasing demand for biodiesel in Brazil, there is also a strong demand for green fuels that decrease the carbon emissions to the atmosphere. This demand lead to the insertion of biodiesel in commercial diesel. However, there are problems related to this mixture, one of the most important is the decrease of the oxidative stability, which is normally solved by the use of antioxidants additives also increasing the cost of the final product. An alternative to the use of additives, in order to improve biodiesel's properties, is the selective hydrogenation of this fuel. The scope of this work is to study the hydrogenation of soy biodiesel employing a magnetic core-shell, platinum based catalysts, which can be retrieved by the use of magnetic fields, reducing the costs due to material loss. The catalysts are $\mathrm{Fe}_{3} \mathrm{O}_{4} @ \mathrm{mSiO}_{2} @ \mathrm{Pt}$ and $\mathrm{Fe}_{3} \mathrm{O}_{4} @ \mathrm{mSiO}_{2} @ \mathrm{Pt} / \mathrm{Pd}$. The catalysts were reused 3 and 4 times, respectively, without considerable loss of activity. The use of $\mathrm{Fe}_{3} \mathrm{O}_{4} @ \mathrm{mSiO}_{2} @ \mathrm{Pt}$ for hydrogenation, increased the level of methyl oleate in over $21 \%$ compared to raw biodiesel, resulting in a product with higher oxidative stability, without compromising the viscosity or melting point original properties, also was noted a high selectivity comparable to hydrogenation employing ionic solvents studies. Tests with ionic solvents showed that they influence the reaction in a negative way, decreasing the velocity or preventing the reaction. In this work is shown the applicability of platinum based magnetic catalysts for the improvement of biodiesel by hydrogenation.
\end{abstract}




\section{Índice}

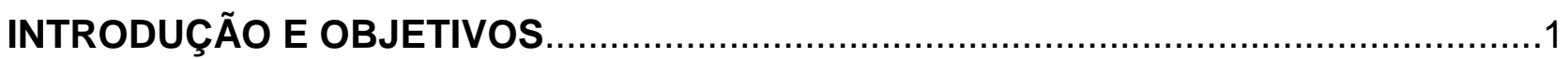

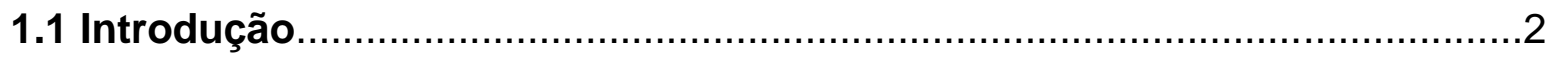

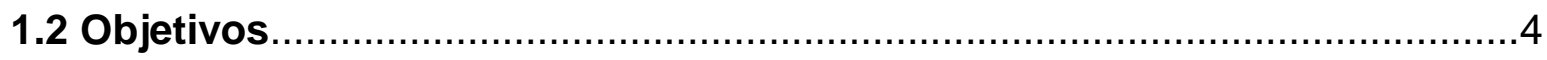

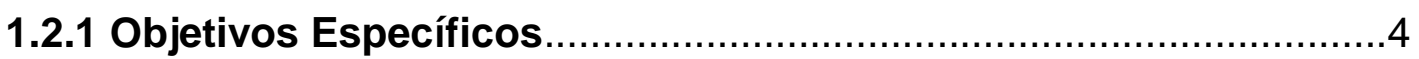

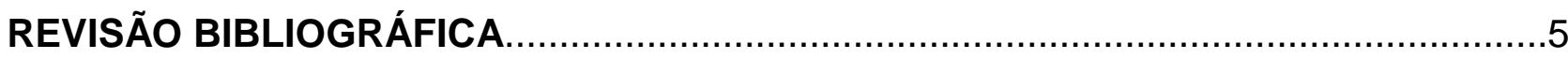

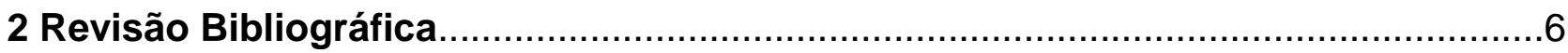

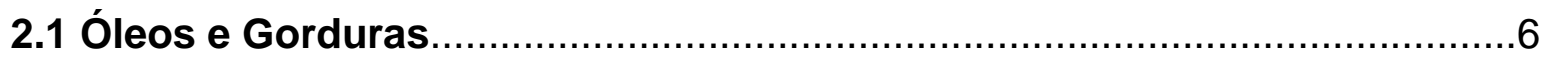

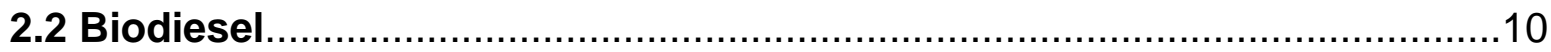

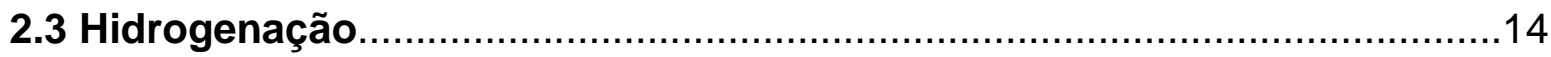

2.4 Uso de Líquidos lônicos na Hidrogenação.....................................17

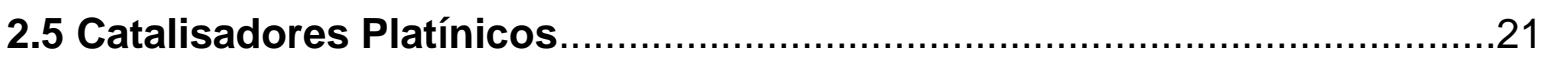

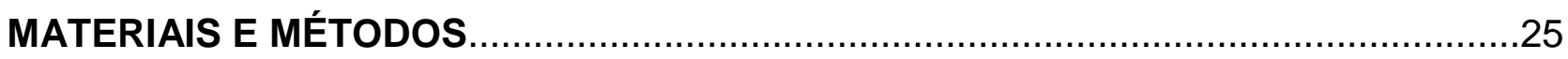

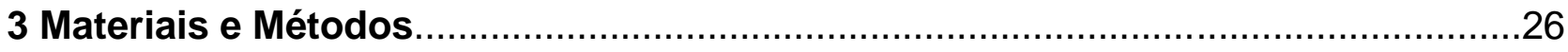

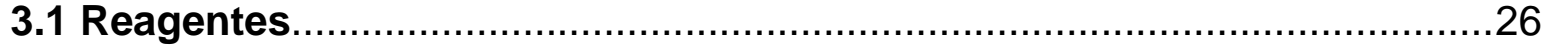

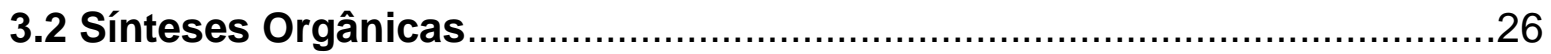

3.2.1 Síntese dos Ésteres Metílicos...............................................26

3.2.2 Sínteses dos Líquidos lônicos............................................27

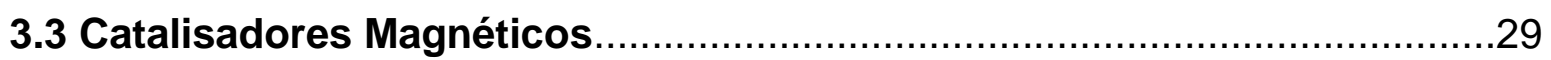

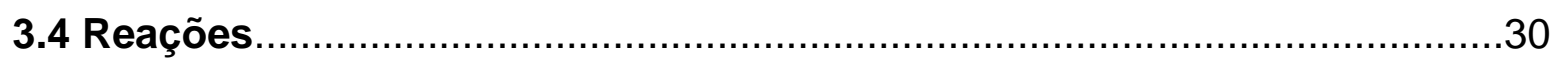

3.4.1 Reações de Hidrogenação.......................................................

3.5 Análises Químicas e Físico-Químicas...................................................31

3.5.1 Cromatografia Líquida de Alta Eficiência.....................................31

3.5.2 Estabilidade Oxidativa....................................................... 31

3.5.3 Viscosidade e Densidade ..........................................................

3.5.4 Microscopia Eletrônica de Varredura.....................................32

3.5.5 Calorimetria Exploratória Diferencial.................................... 32

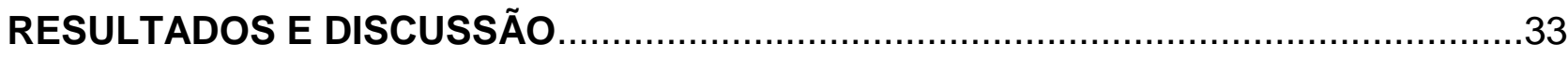

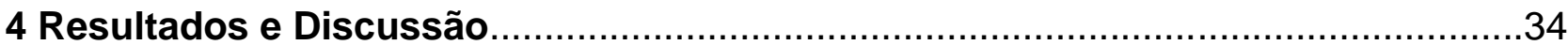

4.1 Reações de Hidrogenação do Biodiesel de Soja.....................................34

4.1.1 Primeira etapa: estudo da proporção (catalisador : biodiesel) ideal

4.1.2 Segunda etapa: estudo da influência da pressão de $\mathrm{H}_{2}$, 
temperatura e tempo no meio reacional.

4.1.3 Terceira Etapa: Estudo do reciclo dos catalisadores para a reação de hidrogenação de biodiesel sob condições reacionais fixas

4.1.4 Quarta etapa: Estudo da influência dos líquidos iônicos nas reações de hidrogenação de biodiesel de soja

4.2 Análises Físico-Químicas dos Produtos Hidrogenados............................49

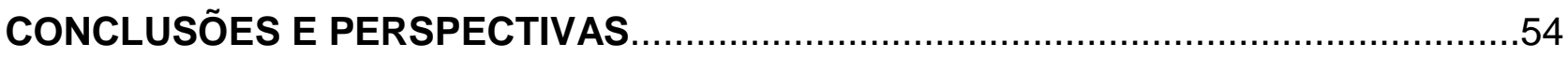

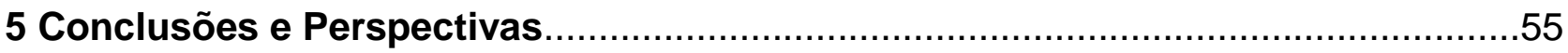

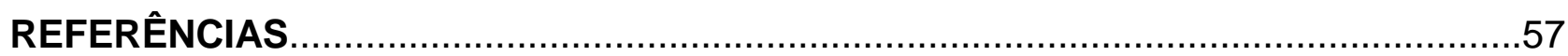

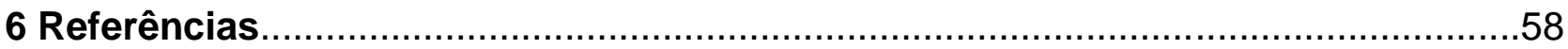

ANEXOS

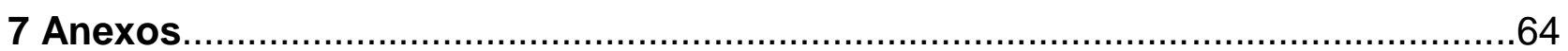

7.1 Limite de detecção e desvio padrão obtido pela curva analítica................64

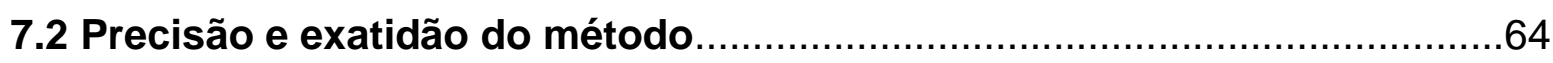

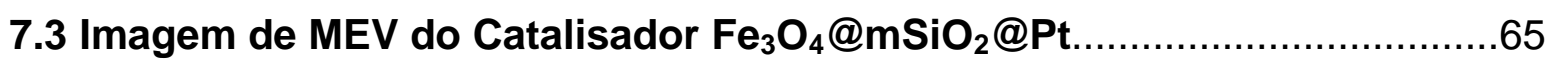




\section{Lista de Abreviaturas e Acrônimos}

ASTM: American Standard Testing Methods

ANP: Agência Nacional do Petróleo, Gás Natural, e Biocombustíveis

CLAE: Cromatografia Líquida de Alta Eficiência

CED: Calorimetria Exploratória Diferencial

Core-Shell: Núcleo-Casca

EMAG: Ester Metílico de Ácido Graxo

EN: European Normalization

LD: Limite de detecção

MEV: Microscopia Eletrônica de Varredura

$\mathrm{Pd}(\mathrm{OAc})_{2}$ : Acetato de Paládio

SD: Standard Deviation

UV: Ultravioleta 


\section{Lista de Tabelas}

Tabela 1. Composições aproximadas dos principais ácidos graxos em diferentes óleos vegetais.

Tabela 2. Produção de biodiesel B100 total no Brasil de 2010 a 2016

Tabela 3. Porcentagem de isômero trans de produtos de hidrogenação sob mesmas condições com catalisadores de $\mathrm{Pd} / \mathrm{C}$ e Ni comercial.

Tabela 4. Propriedades físico-químicas dos líquidos iônicos baseados no cátion 1-alquil3-metil-imidazol e ânion X

Tabela 5. Hidrogenação de biodiesel com diferentes catalisadores.

Tabela 6. Hidrogenação de biodiesel com solvente iônico. .22

Tabela 7. Resultados de hidrocraqueamento de óleos de mamona e soja na presença de $\mathrm{Fe}_{3} \mathrm{O}_{4} @ \mathrm{SiO}_{2} \mathrm{NH}_{2} \mathrm{Rh}$ sob diferentes condições. .23

Tabela 8. Condições reacionais de reações de hidrogenação de biodiesel .30

Tabela 9. Porcentagens dos ésteres metílicos de soja hidrogenados com diferentes massas de catalisador de Pt.

Tabela 10. Porcentagens dos ésteres metílicos de soja hidrogenados com diferentes massas de catalisador de Pt/Pd.

Tabela 11. Porcentagens dos ésteres metílicos de soja hidrogenados com diferentes pressões para o catalisador de Pt.

Tabela 12. Porcentagens dos ésteres metílicos de soja hidrogenados com diferentes pressões para o catalisador de $\mathrm{Pt} / \mathrm{Pd}$.

Tabela 13. Porcentagens dos ésteres metílicos de soja hidrogenados com diferentes temperaturas para o catalisador de $\mathrm{Pt}$.

Tabela 14. Porcentagens dos ésteres metílicos de soja hidrogenados com diferentes temperaturas para o catalisador de $\mathrm{Pt} / \mathrm{Pd}$.

Tabela 15. Densidade e viscosidade do biodiesel, produtos de hidrogenação deste e valores de densidade e viscosidade estabelecidos pela ANP.

Tabela 16. Valores de Densidade de ésteres metílicos puros

Tabela 17. Limites de detecção para os principais ésteres metílicos na composição do biodiesel se soja. 
Tabela 18. Precisão do método de análise de ésteres metílicos.......................................64

Tabela 19. Exatidão do método de determinação de EMAGs por CLAE-UV.....................65 


\section{Lista de Figuras}

Figura 1. Etapas de formação de ácidos graxos e glicerol a partir da hidrólise de triacilgricerídeos

Figura 2. Alguns dos principais ácidos graxos presentes nos óleos e gorduras. .7

Figura 3. Mecanismo de formação de radicais alílicos em ácidos graxos insaturados.......9

Figura 4. Gráfico de representação das matérias primas para produção de biodiesel no Brasil, Janeiro de 2015.

Figura 5. Reação de transesterificação de triacilgricerídeo.

Figura 6. Reação simplificada da hidrogenação do linolenato de metila.

Figura 7. Mecanismo de hidrogenação e isomerização de olefinas .15

Figura 8. À esquerda: cátion 1-alquil-3-metilimidazólio e à direita: contra-íons 19

Figura 9. Etapas resumidas das reações de síntese do $\mathrm{BMI} . \mathrm{BF}_{4}$ .27

Figura 10. Porcentagens dos ésteres metílicos de soja hidrogenados com diferentes tempos reacionais para o catalisador de Pt.

Figura 11. Porcentagens dos ésteres metílicos de soja hidrogenados com diferentes tempos reacionais para o catalisador de $\mathrm{Pt} / \mathrm{Pd}$.

Figura 12. Porcentagens de ésteres metílicos em função do reciclo do catalisador......

Figura 13. Porcentagens de ésteres metílicos em função do tempo de reação de hidrogenação com solvente iônico BMI.BF 4

Figura 14. Microscopia Eletrônica de Varredura do catalisador $\mathrm{Fe}_{3} \mathrm{O}_{4} @ \mathrm{mSiO}_{2} @ \mathrm{Pt}$ após

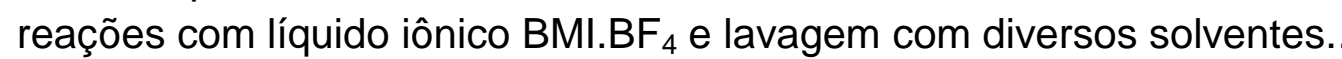

Figura 15. Porcentagens de ésteres metílicos em função do tempo de reação de hidrogenação com solvente iônico BMI.NTf ${ }_{2}$.

Figura 16. Gráficos de estabilidade oxidativa do A: Biodiesel, B: amostra 2 e C: amostra 6.

Figura 17. Gráfico de calorimetria exploratória diferencial do biodiesel, amostra 2 e amostra 6 de $-50^{\circ} \mathrm{C}$ a $50^{\circ} \mathrm{C}$.

Figura 18. MEV do catalisador $\mathrm{Fe}_{3} \mathrm{O}_{4} @ \mathrm{mSiO}_{2} @ P t$. Aumento de 3.000 x. 
INTRODUÇÃO E OBJETIVOS 


\subsection{Introdução}

No início do século XX Rudolf Diesel empregou em seus motores o petróleo cru e o óleo de amendoim como combustíveis. Devido ao baixo preço e à alta disponibilidade, o petróleo foi selecionado como combustível para motores à combustão interna na época. ${ }^{1}$ Pode-se interpretar esta data como o início do uso dos óleos vegetais como combustíveis de motores à combustão interna. Com os avanços tecnológicos, os motores e os combustíveis foram sofrendo otimizações para ajustes de desempenho e eficiência, sendo que o petróleo cru antes usado, agora passa por varias etapas de refino. $^{1}$

Os óleos vegetais crus voltaram a ser usados em motores à combustão interna durante a primeira metade do século $X X$, em períodos de guerras e crises de abastecimento. ${ }^{2}$ Durante a Segunda Guerra Mundial houve o emprego de óleos vegetais em motores à diesel por diversos países, isto ocorreu em função de cortes de fornecimento e aumento dos preços e da demanda. O Brasil diminuiu o preço dos óleos vegetais com a contenção da exportação destes visando não depender dos preços e das ofertas externas de combustíveis. ${ }^{3}$

A partir da metade do século $X X$ foi notada a importância e influência que o petróleo tem sobre a economia global. Esta influência do petróleo foi traduzida durante três grandes acontecimentos na história do petróleo, os três "Choques do Petróleo", que mudaram o preço e a importância deste drasticamente. Outras crises relacionadas ao petróleo ocorreram antes da Segunda Guerra Mundial, porém estas crises, segundo alguns autores, foram impulsionadores da Primeira e Segunda Guerras Mundiais, além de vários conflitos entre países produtores de petróleo e aliados.

O primeiro "Choque do Petróleo" foi em 1973, empreitado pela Organização dos Países Árabes Exportadores de Petróleo, a OAPEC. Uma das hipóteses diz que ocorreu em função de os principais fornecedores de petróleo no Oriente Médio serem informados de que o petróleo é um bem não renovável, porém é possível que este choque tenha ocorrido, principalmente em represália aos acontecimentos da guerra de Yom Kippur, em Outubro de 1973, quando Israel obteve vitória contra Síria e Egito. Imediatamente a oferta do produto caiu e o preço foi elevado em $400 \%$ em apenas três meses, vendas para os Estados Unidos e Europa foram embargadas neste período. ${ }^{4}$ 
O Segundo Choque do Petróleo ocorreu em 1979 em função da paralisação da produção de petróleo no Irã, proporcionada pela revolução Islâmica promovida pelo aiatolá Khomeini contra o governo pouco popular, corrupto e, considerado pelos nativos árabes como ocidentalista, do Xá Mohammad Reza Pahlevi. ${ }^{5}$

Por último o Terceiro Choque do Petróleo ocorreu com a Guerra do Golfo, quando o Iraque tentou anexar o Kuwait alegando que este território fazia parte do território Iraquiano. Neste evento, o golfo pérsico foi fechado e a compra de petróleo do Iraque e do Kuwait foi bloqueada. Logo uma resposta liderada pelos Estados Unidos da América forçaram a retirada das tropas Iraquianas do Kuwait. Porém o preço do petróleo subiu e foi notada a incerteza quanto à credibilidade do presidente iraquiano Saddam Hussein, além disso houve um enorme impacto ambiental causado pela queima de poços de petróleo que durou uma média de dez meses e liberação de petróleo no Golfo Pérsico, contaminando o Oceano Índico e matando milhares de animais desta região. ${ }^{6}$

Em função dos ocorridos durante o século XX com relação ao petróleo e os conflitos envolvendo este, foi incentivado desenvolvimento de novos biocombustíveis e o aprimoramento dos biocombustíveis já existentes para adequação aos motores à combustão interna, a fim de diminuir a dependência de petróleo. Dois processos ganharam destaque: a transesterificação e o craqueamento de óleos vegetais e animais para a produção de biodiesel e bio-óleo. Estes geram produtos adequados quanto às características físico-químicas para o uso em adição e substituição aos derivados de petróleo, e paralelamente, visam reduzir as emissões de carbono, enxofre e outros gases nocivos, pois estão teoricamente dentro de um ciclo de carbono fechado. ${ }^{7}$

O biodiesel teve seus primeiros registros de estudos na Bélgica, e em 1937 foi registrada a primeira patente deste processo para a síntese de combustível. Desde então este combustível foi estudado intensivamente e testado em motores, sendo usado mundialmente devido à suas características semelhantes ao diesel fóssil. ${ }^{8,9}$

É possível notar que desde 1937, pouco foi mudado no processo de obtenção de biodiesel em larga escala, este fator mostra o quão importante é o estudo de novas rotas para obtenção deste combustível.

No Brasil, a implementação do biodiesel como combustível foi feita pelo Programa Nacional de Produção e Uso do Biodiesel (PNPB), no ano de 2004, porém a 
exigência da mistura deste no diesel fóssil começou em 2008 com 2\%, e até 2010 passou a ser $5 \%$. Hoje o biodiesel é, por exigência, $7 \%$ da mistura do diesel comercial. ${ }^{10}$

Junto a estas adições de biodiesel no combustível Brasileiro veio a menor necessidade de importação de combustíveis, porém foram notados problemas relacionados a este, como a formação de borras nos motores, degradação deste combustível no armazenamento, e mudanças nas propriedades do diesel comercial.

O biodiesel é um combustível de fontes vegetais e, portanto, degradável, principalmente por meio de oxidação. A adição de antioxidantes é um meio para sanar problemas de degradação do biodiesel, porém devido aos preços e outros fatores, esta opção não é tão atrativa e muitas vezes apresenta problemas.

Neste trabalho é proposta uma alternativa para o melhoramento da estabilidade do biodiesel sem influenciar suas propriedades físico-químicas, por meio da hidrogenação com catalisadores de fácil recuperação, diminuindo custos relacionados a este processo.

\subsection{Objetivos}

Este trabalho tem como objetivo investigar o desempenho de catalisadores platínicos nanométricos em suportes mesoporosos em reações de hidrogenação de biodiesel para melhoramento das propriedades físico-químicas deste. É proposta também novas tecnologias de recuperação de catalisadores com solventes de transferência de fases iônicos e por meios magnéticos, onde os catalisadores são sintetizados cobrindo partículas magnéticas de $\mathrm{Fe}_{3} \mathrm{O}_{4}$, facilitando $\mathrm{o}$ isolamento $\mathrm{e}$ recuperação dos catalisadores.

\subsubsection{Objetivos Específicos}

Realizar reações de hidrogenação do biodiesel com os catalisadores de $\mathrm{Fe}_{3} \mathrm{O}_{4} @ \mathrm{mSiO}{ }_{2} @ \mathrm{Pt}$ e $\mathrm{Fe}_{3} \mathrm{O}_{4} @ \mathrm{mSiO}{ }_{2} @ \mathrm{Pt} / \mathrm{Pd}$ sob diferentes condições, verificar o reciclo dos catalisadores deste trabalho, realizar reações de hidrogenação com a presença de solventes iônicos, verificar a influência destes na seletividade dos produtos formados e verificar a influência da hidrogenação nas propriedades físico-químicas do biodiesel. 
REVISÃO BIBLIOGRÁFICA 


\section{Revisão Bibliográfica}

\section{1 Óleos e Gorduras}

Óleos e gorduras são uma mistura de materiais graxos, insolúveis em água, compostos principalmente por ácidos graxos e seus derivados glicerídicos. Segundo a Agência Nacional de Vigilância Sanitária (ANVISA) na resolução n 85 de 2004, óleos são as misturas de materiais graxos com ponto de fusão inferior a $25^{\circ} \mathrm{C}$ e gorduras são as misturas de materiais graxos com ponto de fusão igual ou superior a $25^{\circ} \mathrm{C}$.

Os triacilglicerídeos são cadeias longas de ácidos graxos reagidos com glicerol. Quando há hidrólise destes, há a formação de ácidos graxos, diacilglicerídeos, monoacilglicerídeos e glicerol. O mecanismo desta reação pode ser visto abaixo.<smiles>[R]C(=O)OCC(COC([R])=O)OC([R])=O</smiles>

Triacilglicerídeo<smiles>OCC(O)CO</smiles>

\section{Glicerol}<smiles>[R2]C(=O)OC([N+])C(OC([R])=O)C(CO)OC([R])=O</smiles>

Diacilglicerídeo<smiles>[3H]CO</smiles><smiles>[R]C(=O)OC(O)C(O)CO</smiles>

\section{Monoacilglicerídeo}

Figura 1: Etapas de formação de ácidos graxos e glicerol a partir da hidrólise de triacilgricerídeos. ( $R_{1}, R_{2}$ e $R_{3}$ : cadeias carbônicas). Adaptado de Demirbas et al. (2008). ${ }^{11}$ 
Ácidos graxos são cadeias longas com um grupo ácido carboxílico, podendo haver insaturações, normalmente na posição cis. Alguns dos principais ácidos graxos encontrados nos óleos e gorduras vegetais e animais estão ilustrados abaixo.

A

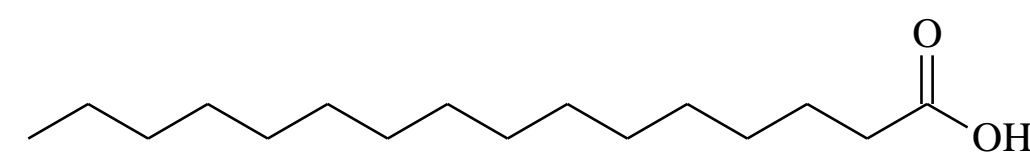<smiles>[B]CCCCCCCCCCCCCCCCC(=O)O</smiles><smiles>CC/C=C\C/C=C\C/C=C\CCCCCCCC(=O)O</smiles>

Figura 2: Alguns dos principais ácidos graxos presentes nos óleos e gorduras: A: ácido palmítico, B: ácido esteárico, C: ácido oleico, D: ácido linoleico, E: ácido linolênico e $\mathrm{F}$ : ácido ricinoleico.

É importante notar a geometria dos ácidos graxos saturados, insaturados e saturados na posição trans. Esta geometria é determinante para o "empacotamento" das moléculas, possibilitando que elas se aproximem mais no caso de predominância de cadeias saturadas ou insaturadas na posição trans e assim podendo tornar o material 
graxo em sólido à temperatura ambiente e por definição uma gordura. No caso de haver predominância de ácidos graxos insaturados com uma ou mais insaturações na posição cis, haverá menor grau de empacotamento das cadeias, favorecendo a mistura ser líquida a $25^{\circ} \mathrm{C}$.

Normalmente a indicação dos ácidos graxos é feita referindo-se ao número de átomos de carbono na cadeia seguido de dois pontos e em seguida o número de insaturações presentes, podendo ainda ser referido se a insaturação é cis ou trans. Exemplo do ácido oleico: 18:1 cis. Na tabela abaixo são apresentadas as composições graxas de alguns óleos e gorduras vegetais seguindo este modelo de nomenclatura de ácidos graxos. ${ }^{12}$

Tabela 1: Composições aproximadas dos principais ácidos graxos em diferentes óleos vegetais. $^{2,13}$

\begin{tabular}{|c|c|c|c|c|c|c|}
\hline \multicolumn{7}{|c|}{ Composição de Ácidos Graxos (\% m/m) } \\
\hline Óleo & $\begin{array}{c}\text { Ácido } \\
\text { Linolênico }\end{array}$ & $\begin{array}{c}\text { Ácido } \\
\text { Linoleico }\end{array}$ & $\begin{array}{c}\text { Ácido } \\
\text { Oleico }\end{array}$ & $\begin{array}{c}\text { Ácido } \\
\text { Esteárico }\end{array}$ & $\begin{array}{c}\text { Ácido } \\
\text { Palmítico }\end{array}$ & $\begin{array}{c}\text { Ácido } \\
\text { Ricinoleico }\end{array}$ \\
\hline Soja & 6 & 52 & 24 & 4 & 14 & 0 \\
\hline Mamona & 1 & 5 & 3 & 1 & 2 & 88 \\
\hline Dendê & 0 & 14 & 44 & 7 & 35 & 0 \\
\hline Milho & 1 & 60 & 25 & 2 & 12 & 0 \\
\hline Girassol & 0 & 74 & 17 & 3 & 6 & 0 \\
\hline Coco & 0 & 2 & 7 & 3 & 10 & 0 \\
\hline Colza & 8 & 22 & 65 & 1 & 4 & 0 \\
\hline Amendoim & 1 & 32 & 48 & 2 & 12 & 0 \\
\hline Banha de & 0 & 11 & 44 & 14 & 24 & 0 \\
\hline Porco & 1 & 3 & 42 & 19 & 23 & 0 \\
\hline Sebo Bovino & & & & & & 0 \\
\hline
\end{tabular}

Algumas fontes oleaginosas, principalmente as vegetais, possuem predominantemente ácidos graxos poli-insaturados, fazendo com que estes materiais graxos sejam mais facilmente oxidáveis e tenham menor prazo de validade que os óleos e gorduras com predominância de ácidos monoinsaturados ou saturados. 
Também é possível notar que apenas o óleo de mamona possui o ácido ricinoleico, mostrado na Figura 2. Este ácido além de garantir uma conformação diferenciada nas cadeias graxas, garante também maior hidrofilicidade ao óleo de mamona em função do grupo hidroxila presente na cadeia de carbonos, que oferece um sítio eletronegativo à esta molécula.

Os ácidos graxos poli-insaturados são mais instáveis e oxidáveis devido à presença das duplas ligações não conjugadas, separadas por um carbono $\mathrm{CH}_{2}$, os hidrogênios desse carbono são facilmente removidos por grupos radicalares ou nucleofílicos, além de fontes de radiação. Esta remoção de hidrogênio forma um radical que, por estar entre duplas ligações, é estabilizado sendo um radical alílico e portanto, quanto mais duplas ligações maior será a estabilização do radical alílico e maior sua reatividade. $O$ mecanismo da formação deste radical pode ser verificado na figura abaixo. ${ }^{14}$
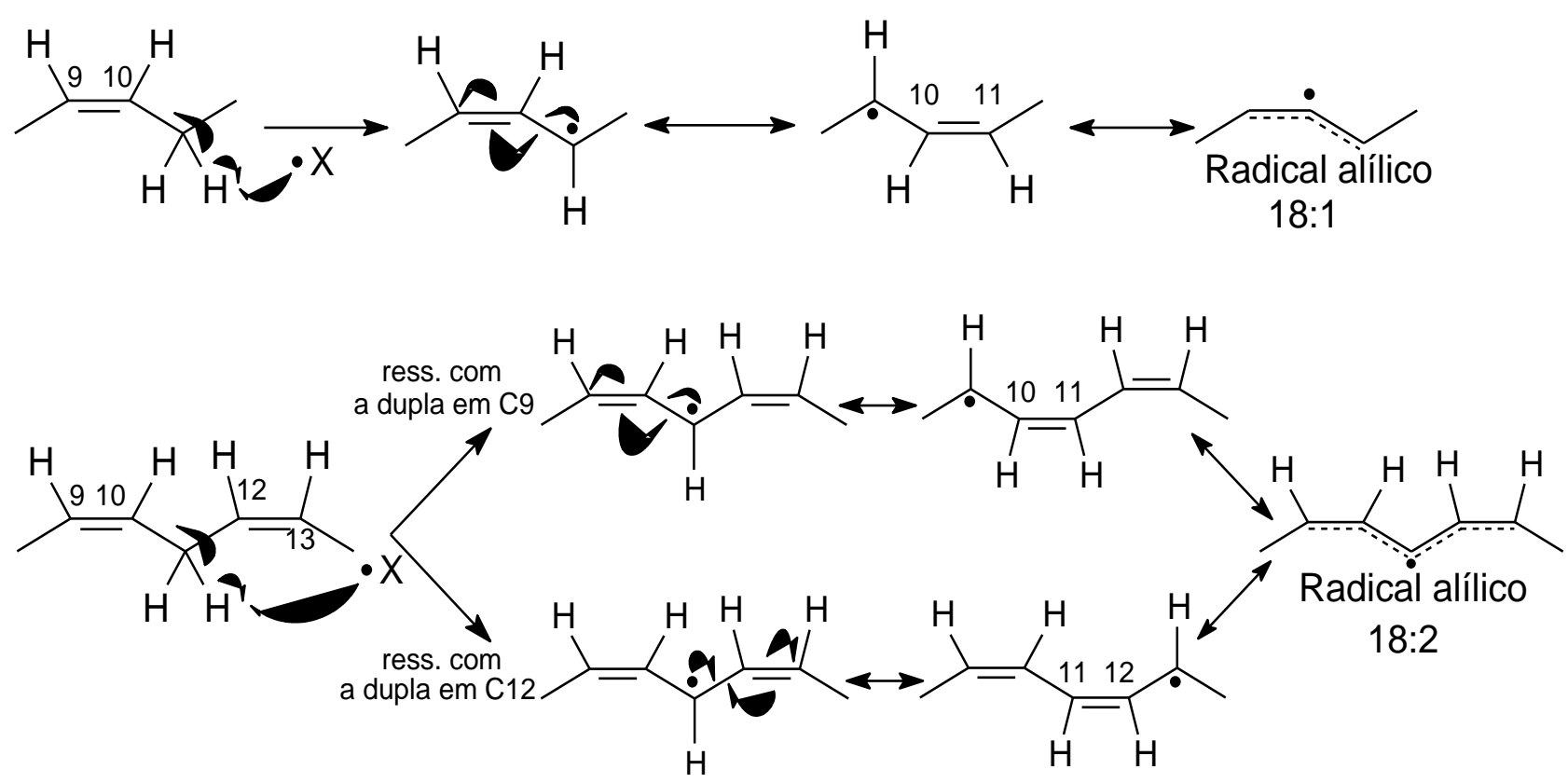

Figura 3: Mecanismo de formação de radicais alílicos em ácidos graxos insaturados. ${ }^{14}$

Esta reação é iniciada por um ataque radicalar no hidrogênio vizinho à insaturação da cadeia, gerando assim um radical na cadeia que, junto com um elétron da dupla ligação, geram uma nova dupla. Este processo fica alternando em ressonância formando o radical alílico. No caso de duas insaturações separadas por um $-\mathrm{CH}_{2}-\mathrm{O}$ 
mecanismo será o mesmo, porém o elétron do radical formado poderá atacar em ambos os lados, formando um grupo de ressonância entre as duas duplas.

É verificável que a formação do radical alílico para a cadeia de 18:1 é estabilizada apenas por uma ligação dupla. Já na formação do radical alílico na cadeia de 18:2 há a estabilização do radical por duas ligações duplas vizinhas proporcionando ressonância e dando grande estabilidade à molécula formada, o mesmo fenômeno ocorre para as cadeias de 18:3.

\subsection{Biodiesel}

O biodiesel consiste em uma mistura de ésteres metílicos (principalmente) ou etílicos de ácidos graxos de cadeias longas, produzidos por esterificação ou transesterificação de materiais graxos e que atenda as especificações da Agência Nacional de Petróleo. ${ }^{15}$

O biodiesel foi introduzido no mercado brasileiro a partir de 2005, sendo que em 2008 o biodiesel era, por obrigatoriedade, no mínimo $2 \%$ da composição total do diesel comercial e em 2014 passou a ser no mínimo 7\% da composição total do diesel comercial. Porém esta porcentagem de biodiesel no combustível tende a aumentar nos próximos anos. ${ }^{16}$

No Brasil a principal rota de obtenção de biodiesel é por meio da transesterificação de óleos vegetais, principalmente óleo de soja, que corresponde a uma média anual de $74,72 \%$ da matéria prima para biodiesel no Brasil segundo a Agência Nacional do Petróleo (ANP). Outras matérias primas para a produção de biodiesel no Brasil são: gordura bovina, óleo de algodão, óleo de fritura, gordura de porco, gordura de frango e outros. ${ }^{16}$

A soja ganhou grande importância no Brasil, inicialmente, devido a uma oportunidade econômica, quando esta teve uma alta nos preços, na década de 70 , fazendo com que a produção desta aumentasse consideravelmente. Outra vantagem era de que a soja era produzida no momento de entressafra da produção de soja dos Estados Unidos e entressafra da produção brasileira de trigo. Estes foram apenas 2 dos principais fatores que tornaram a soja o principal produto agrícola do Brasil, e principalmente por isso o óleo soja é o mais utilizado na produção de biodiesel. ${ }^{17}$ 


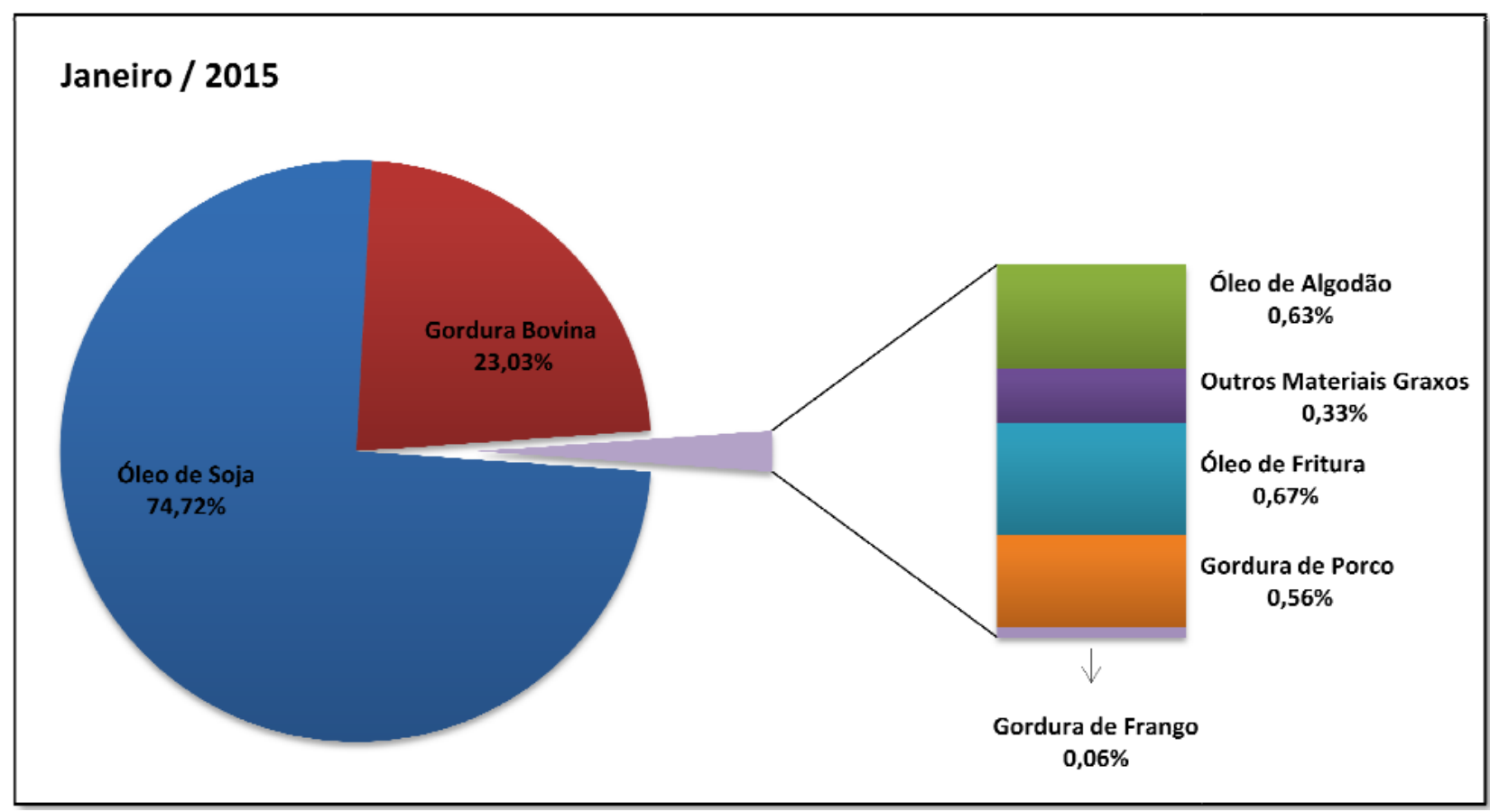

Figura 4: Gráfico de representação das matérias primas para produção de biodiesel no Brasil janeiro de $2015 .^{16}$

Há grande importância do óleo de soja para a produção de biodiesel no Brasil, e a expectativa é de que a produção aumente em função dos acréscimos de biodiesel no diesel comercial nos próximos anos, seguindo as tendências experimentais de alguns países europeus. Fazendo uma progressão da evolução da produção de biodiesel no Brasil exemplificada na Tabela 2 é possível conferir essa afirmativa. ${ }^{18}$ 
Tabela 2: Produção de biodiesel B100 $\left(\mathrm{m}^{3}\right)$ total no Brasil de 2010 a $2016 .{ }^{19}$

\begin{tabular}{|c|c|c|c|c|c|c|c|}
\hline \multicolumn{8}{|c|}{ Ano } \\
\hline Dados & 2010 & 2011 & 2012 & 2013 & 2014 & 2015 & 2016 \\
\hline Janeiro & 147.435 & 186.327 & 193.006 & 226.505 & 245.215 & 319.546 & 271.388 \\
\hline Fevereiro & 178.049 & 176.783 & 214.607 & 205.738 & 240.529 & 303.594 & \\
\hline Março & 214.150 & 233.465 & 220.872 & 230.752 & 271.839 & 322.692 & \\
\hline Abril & 184.897 & 200.381 & 182.372 & 253.591 & 253.224 & 324.526 & \\
\hline Maio & 202.729 & 220.484 & 213.021 & 245.934 & 242.526 & 338.851 & \\
\hline Junho & 204.940 & 231.573 & 214.898 & 236.441 & 251.517 & 322.185 & \\
\hline Julho & 207.434 & 249.897 & 230.340 & 260.671 & 302.971 & 341.094 & \\
\hline Agosto & 231.160 & 247.934 & 254.426 & 247.610 & 314.532 & 344.038 & \\
\hline Setembro & 219.988 & 233.971 & 252.243 & 252.714 & 312.665 & 330.388 & \\
\hline Outubro & 199.895 & 237.885 & 251.416 & 277.992 & 321.603 & 359.166 & \\
\hline Novembro & 207.868 & 237.189 & 245.321 & 265.176 & 316.627 & 324.662 & \\
\hline Dezembro & 187.856 & 216.870 & 244.962 & 214.364 & 348.962 & 306.526 & \\
\hline Total do Ano & 2.386.399 & 2.672 .760 & 2.717 .483 & 2.917.488 & 3.422 .210 & 3.937 .269 & 271.388 \\
\hline
\end{tabular}

Devido ao grande volume de soja produzido e sendo esta a principal matéria prima na produção de biodiesel, a rota de transesterificação é a mais praticada no Brasil para a obtenção de biodiesel. A esterificação de óleos e gorduras vegetais também é praticada em menor escala, quando há porcentagem de ácidos graxos na composição é superior a $5 \%$. 


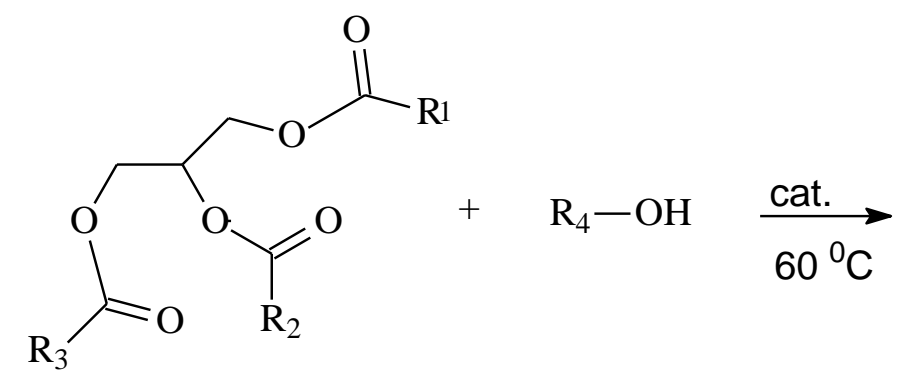<smiles>[R]OC([R])=O</smiles>

Triglicerídeo<smiles>[R]OC([R])=O</smiles><smiles>[R]OC([R])=O</smiles>

Figura 5: Reação de transesterificação de triacilgricerídeo.

Assim como na reação de hidrólise de triacilgricerídeos, a reação de transesterificação ocorre em três etapas, onde o primeiro éster será liberado gerando também um diacilglicerídeo, em seguida o segundo éster será formado junto a um monoacilglicerídeo e por último será liberado o terceiro éster e uma glicerina. Nestas três etapas há a regeneração do catalisador. A glicerina pode ser facilmente separada do éster formado (biodiesel) por diferença de fases. Após a separação pode ser feita uma lavagem do biodiesel com ácido sulfúrico e água deionizada para a remoção de sais e catalisadores em excesso presentes na emulsão.

Após todos estes processos o biodiesel é então seco por vácuo para que não haja água no meio. Esta medida evita a hidrólise dos ésteres e a possível formação de ácidos graxos, aumentando a durabilidade do biodiesel.

Um dos principais problemas nos acréscimos de biodiesel no diesel comercial é a baixa estabilidade oxidativa do óleo de soja e consequentemente de seus ésteres metílicos, pois como é possível notar no mecanismo da Figura 5, a reação de transesterificação não modifica as duplas ligações nos ácidos graxos. Para sanar estes problemas de estabilidade, são empregados antioxidantes, que neutralizam radicais livres, diminuindo agentes oxidantes na mistura. Porém, estes são paliativos pois não ajudam no problema das duplas ligações e não é sabido o comportamento destes com ácidos graxos.

A hidrogenação seletiva é uma possível rota para o aumento da estabilidade oxidativa e manutenção das propriedades físico-químicas do biodiesel, favorecendo a formação de produtos monoinsaturados na posição cis. Estudos já mostraram que metais platínicos são eficazes na hidrogenação seletiva de biodiesel com o emprego de 
solventes iônicos, porém estes estudos se limitaram ao uso de catalisadores de Paládio em diversos suportes. ${ }^{20,21}$

\subsection{Hidrogenação}

A hidrogenação de óleos e gorduras é um processo que é utilizado principalmente para a produção alimentícia, onde é feita de forma a se obter compostos completamente hidrogenados (sem insaturações) que podem ser misturados a óleos insaturados para dar origem a diversos produtos como margarinas. ${ }^{22}$

A hidrogenação de olefinas insaturadas consiste na inserção de hidreto $(H \cdot)$ nas duplas ligações por meio da superfície do catalisador, que gera $\circ \mathrm{H}^{*}$ a partir do gás hidrogênio $\left(\mathrm{H}_{2}\right)$. A superfície catalítica também liga-se às olefinas por meio de interação entre os orbitais possibilitando então a entrada de hidrogênios nas cadeias carbônicas.

A hidrogenação de uma cadeia poli-insaturada segue por etapas, gerando produtos parcialmente hidrogenados (visto que a probabilidade de um contato de todas as duplas ligações com a superfície do catalisador é pequena devido à conformação da cadeia), este produtos seguem por sucessivas hidrogenações até a formação de um produto completamente saturado. É possível ver uma reação de hidrogenação simplificada de um alceno na Figura 6. 


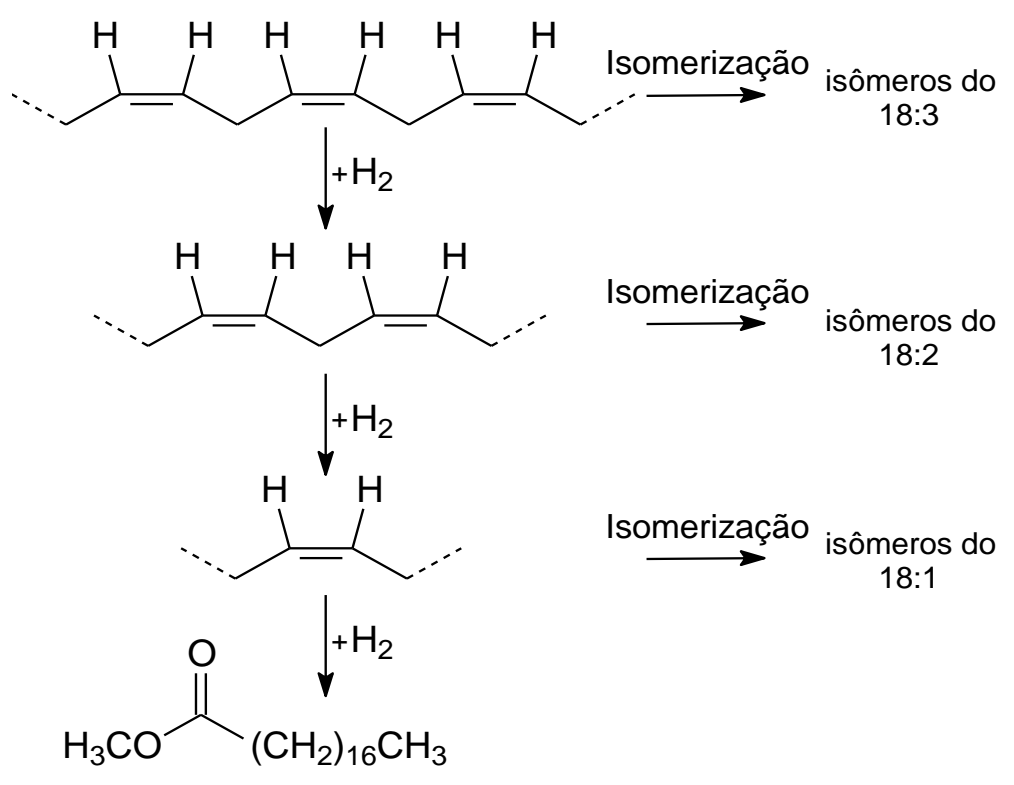

Figura 6: Hidrogenação do linolenato de metila. Adaptada de Bouriazos et al. (2007). ${ }^{23}$

Há também a possibilidade de haver uma rotação da olefina na superfície do catalisador, sem a hidrogenação, gerando um isômero trans da olefina, como mostrado à esquerda da Figura 7 a seguir. Esta possibilidade de geração de isômeros trans pode ser explicada pela menor energia $\left(\Delta \mathrm{H}^{0}\right)$ do composto trans com relação ao seu isômero cis. Esta diferença energética é facilmente compreendida quando observamos a conformação destas duas moléculas exemplificadas na Figura $2 .{ }^{22}$<smiles>[R]/C=C\C[R]</smiles>

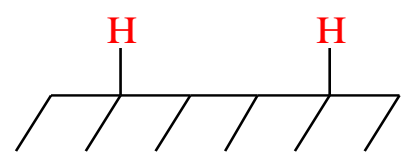

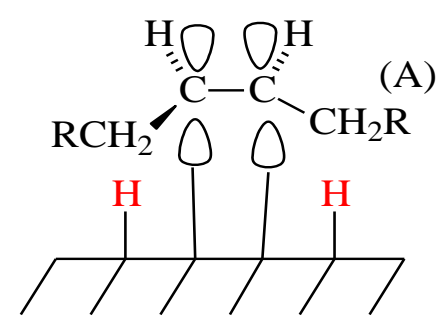

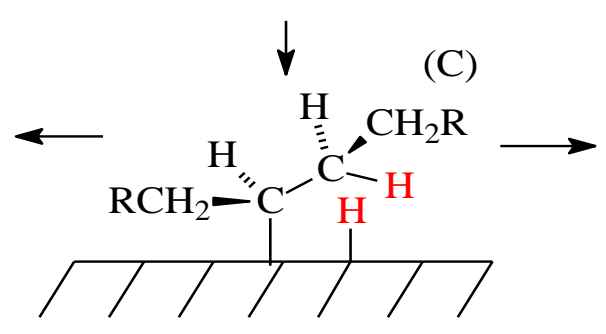

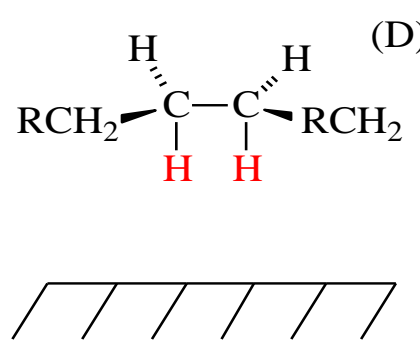

Figura 7: Mecanismo de hidrogenação e isomerização de olefinas. Adaptada Pinho, David M. M. (2013). ${ }^{22}$ 
Devido à cinética desta reação, a hidrogenação exige a presença de catalisadores, uma vez que sem estes a reação só ocorre em condições drásticas de pressão e temperatura. ${ }^{22}$ Os catalisadores comumente utilizados são metálicos dos grupos VIII, IX, X e XI como o Ni, Cu, Co, Pd, Pt, Ru e Rh além de zeólitas. ${ }^{24,25}$

Hoje há um grande foco no estudo dos metais platínicos como catalisadores, Pd, $\mathrm{Ru}, \mathrm{Rh}$ e Pt em diversos suportes, pois se mostraram eficazes para reações de hidrogenação e hidrocraqueamento. ${ }^{24,25,26}$ Estes catalisadores, também podem ser empregados em reações de hidrogenação seletiva com ótima atividade quando comparados ao Níquel, proporcionando melhor seletividade para a formação de ésteres com apenas uma insaturação no caso do $\mathrm{Pd}$ e $\mathrm{Pt}^{21,}{ }^{27}$ Estes catalisadores também são reportados no uso para reforma de hidrocarbonetos e mesmo hidrogenação de $\mathrm{CO} / \mathrm{CO}_{2}{ }^{28}$ Os suportes destes catalisadores podem variar de acordo com o tipo de reação e metal catalisador. ${ }^{22,28}$

Um exemplo desta melhor aplicabilidade dos catalisadores Platínicos frente ao Níquel, além da menor toxicidade ${ }^{29}$, é a melhor seletividade para a formação de isômeros cis na hidrogenação de óleos, além da conhecida melhor estabilidade à oxidação destes metais. Esta melhor seletividade dos produtos gerados pode ser verificada na Tabela 3 apresentada abaixo. ${ }^{30}$

Tabela 3: Porcentagem de isômero trans de produtos de hidrogenação sob mesmas condições com catalisadores de $\mathrm{Pd} / \mathrm{C}$ e Ni comercial. ${ }^{30}$

\begin{tabular}{cc}
\hline Catalisador & \% trans \\
\hline $\mathrm{Ni}$ & 35 \\
$\mathrm{Pd} / \mathrm{C}$ & 6,5 \\
\hline
\end{tabular}

Para o biodiesel, há grande intenção de uma hidrogenação parcial e seletiva para o isômero cis com uma insaturação (18:1 cis, oleato de metila), este possui melhores propriedades a frio (Ponto de Fusão: $16,3^{\circ} \mathrm{C}$ ) quando comparado com o seu isômero trans (P. F.: $43,7^{\circ} \mathrm{C}$ ) ou o estearato de metila $(18: 0)$ (P. F.: $69,6^{\circ} \mathrm{C}$ ). O oleato de metila possui também melhor estabilidade oxidativa quando comparado com as cadeias de duas ou três insaturações (18:2 e 18:3), por motivos anteriormente discutidos. ${ }^{31,32,33}$ 
Este é um grande desafio: otimizar a produção de biodiesel com alta estabilidade oxidativa e propriedades físico-químicas semelhantes às do diesel fóssil a um baixo custo, o que implica na tentativa de otimização da produção de oleato de metila. Devido a isto, diversos catalisadores e suportes são estudados, além de solventes de transferência de fase. ${ }^{32}$

Uma grande barreira no uso de catalisadores de metais platínicos esta no alto custo e dificuldades na recuperação destes, que exigem processos onerosos para seu reuso. O que torna a catálise platínica um desafio frente aos custos atrelados às perdas de massa de catalisador.

Estudos recentes mostram um novo método simples e eficaz para a recuperação de catalisadores: o emprego de suportes magnéticos. Os suportes magnéticos facilitam a recuperação do catalisador, sendo necessário um simples campo magnético para que o catalisador seja isolado, mesmo quando as partículas são muito pequenas, diminuindo os custos e também a perda de massa de catalisador. E estes modelos de catalisadores são aplicáveis em diversas áreas dentro e fora da catálise, tendo estudos até na área biomédica. ${ }^{34,} 35$ Ainda são necessários mais estudos destes catalisadores na hidrogenação de biocombustíveis.

Outra linha de estudos emprega líquidos iônicos como solventes do catalisador, sendo também um solvente de transferência de fase. Estes estudos mostram que houve grande aumento na seletividade dos produtos formados, mostrando que o uso de um solvente iônico pode auxiliar no aumento do rendimento da hidrogenação seletiva e ainda facilitar na recuperação dos catalisadores, uma vez que há grande tendência de os catalisadores permanecerem em fase iônica..$^{20,36}$

\subsection{Uso de Líquidos lônicos na Hidrogenação}

Os líquidos iônicos são comumente empregados como solvente de transferência de fase, podendo ter diversas propriedades físico-químicas em função de seus contra ânions. Os líquidos iônicos mais promissores são os baseados em 1-alquil-3metilimidazólio. ${ }^{37}$ Primeiramente foram utilizados ânions derivados de ácidos fortes, como o $\mathrm{AlCl}_{3}{ }^{38}$. Posteriormente estes ânions foram substituídos por ânions fracamente coordenados como $\circ \mathrm{BF}_{4}^{-}, \mathrm{PF}_{6}^{-}, \mathrm{CF}_{3} \mathrm{CO}_{2}^{-}$, entre outros. ${ }^{36} \mathrm{~A}$ partir de então os líquidos 
iônicos foram altamente aplicados em pesquisas e processos de catálise e reações orgânicas.

Já foram bem estudadas as propriedades físico-químicas dos líquidos iônicos como visto na Tabela 4, e ainda suas características em reações orgânicas de solvente estabilizante de intermediários e auxiliar na seletividade de produtos formados. ${ }^{39,40,41}$

Tabela 4: Propriedades físico-químicas dos líquidos iônicos baseados no cátion 1-alquil3-metilimidazol e ânion X. Adaptada de Carvalho, M. S. (2008). ${ }^{12}$

\begin{tabular}{|c|c|c|c|c|c|c|c|}
\hline $\mathbf{R}^{\mathbf{a}}$ & $X^{-}$ & $\begin{array}{c}T_{g} \\
\left({ }^{\circ} \mathrm{C}\right)^{b}\end{array}$ & $\begin{array}{c}T_{f} \\
\left({ }^{o} C\right)^{c}\end{array}$ & $\begin{array}{c}T_{d} \\
\left({ }^{\circ} \mathrm{C}\right)^{d}\end{array}$ & $\begin{array}{c}\eta \\
(m P a . s)^{e}\end{array}$ & $\begin{array}{c}D \\
\left(\mathrm{~g} \cdot \mathrm{cm}^{-3}\right)^{\dagger}\end{array}$ & $\begin{array}{c}\sigma \\
\left(\mathrm{mS} . \mathrm{cm}^{-1}\right)^{\mathrm{g}}\end{array}$ \\
\hline Et & $\mathrm{BF}_{4}$ & -92 & 13 & 447 & 37 & 1,28 & 14 \\
\hline$n \mathrm{Pr}$ & $\mathrm{BF}_{4}$ & -88 & -17 & 435 & 103 & 1,24 & 5,9 \\
\hline$n \mathrm{Bu}$ & $\mathrm{BF}_{4}$ & -85 & -80 & 435 & $\begin{array}{c}180 \\
(233)\end{array}$ & 1,21 & $3,5(8,6)$ \\
\hline$n B u$ & $\mathrm{~N}(\mathrm{Tf})_{2}$ & $-{ }^{n}$ & -4 & $>400$ & 69 & 1,43 & 3,9 \\
\hline$n \mathrm{Bu}$ & $\mathrm{PF}_{6}$ & -61 & 10 & - & $\begin{array}{l}219 \\
(312)\end{array}$ & 1,37 & $1,6(6,5)$ \\
\hline$n B u$ & $\mathrm{AlCl}_{4}$ & -88 & - & - & -294 & 1,23 & $(24,1)$ \\
\hline$n B u$ & $\mathrm{CF}_{3} \mathrm{SO}_{3}$ & - & 16 & - & 90 & 1,22 & 3,7 \\
\hline$n \mathrm{Bu}$ & $\mathrm{CF}_{3} \mathrm{CO}_{2}$ & -30 & - & - & 73 & 1,21 & 3,2 \\
\hline
\end{tabular}

a) R é a cadeia alquílica ligada a $N_{1}$ da figura 8 ; b) $T_{g}=$ temperatura de transição vítrea;

c) $T_{f}=$ ponto de fusão; d) $T_{d}=$ temperatura de decomposição; e) $\eta=$ viscosidade a $25^{\circ} \mathrm{C}$ e, entre parênteses, a $30^{\circ} \mathrm{C}$; f) $\mathrm{d}=$ densidade a $25^{\circ} \mathrm{C}$; g) $\sigma=$ Condutividade a $25^{\circ} \mathrm{C}$ e, entre parênteses, a $60^{\circ} \mathrm{C}$. h) (一) valor não disponível na literatura.

As propriedades físico-químicas dos líquidos iônicos são determinadas pelos seus ânions, que interagirão de diferentes maneiras com o cátion do líquido iônico e com os compostos em contato com este solvente. Estas diferentes interações em função dos diferentes ânions podem ser explicadas pelos diferentes tipos de moléculas aniônicas. $\mathrm{Na}$ figura 8 é possível verificar algumas conformações geométricas aproximadas por programas computacionais de um cátion $\left(\mathrm{BMI}^{+}\right)$e diversos ânions. 


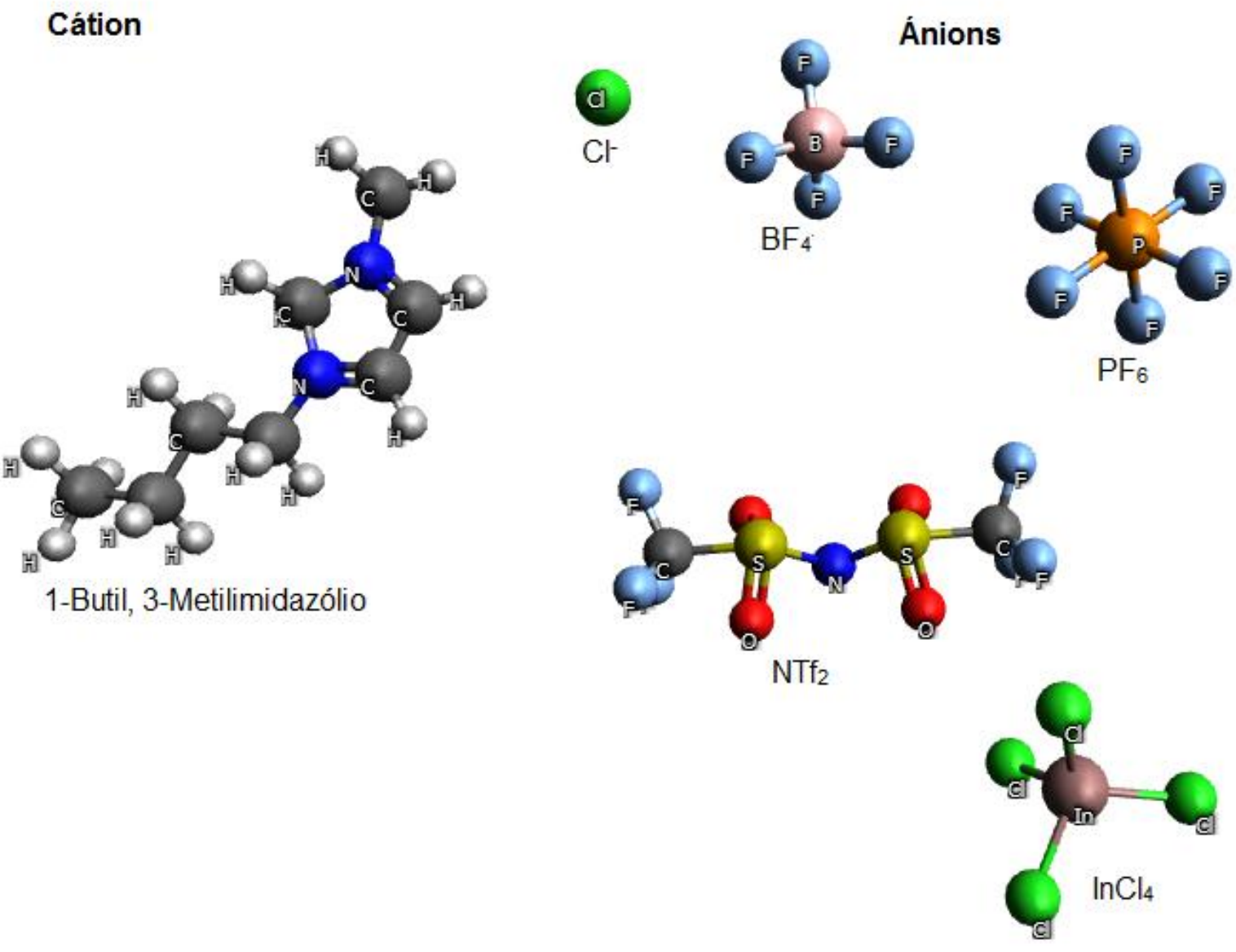

Figura 8: Cátion 1-alquil-3-metilimidazólio e contra-íons.

Os líquidos iônicos foram inicialmente empregados como eletrólitos para baterias. Porém, foi notada a grande aplicabilidade destes como solventes em reações orgânicas, extrações, separações de fases e diversos outros usos.

Para reações orgânicas e catálise os líquidos iônicos tiveram atenção especial devido à sua característica de serem solventes seletivos (dependendo do líquido iônico e do contra íon), proporcionando a formação de determinados produtos ou mesmo como solventes de reagentes específicos nos meios reacionais. Para a catálise, além da seletividade de reagentes e produtos, os líquidos iônicos mostraram aplicabilidade na recuperação de catalisadores que, quando dispersados neste solvente, são mais facilmente separados da reação para reciclo. ${ }^{42}$

Para a reação de hidrogenação de biodiesel, os líquidos iônicos servem como solventes de transferência de fase, facilitado a permeação de hidrogênio na solução, auxiliam no melhoramento da recuperação dos catalisadores e como auxiliares na 
seletividade dos produtos gerados, proporcionando a geração de produtos monoinsaturados. Isto devido à menor solubilidade de compostos monoinsaturados que de compostos poli-insaturados em líquidos iônicos, diminuindo assim o contato dos compostos monoinsaturados com o catalisador. ${ }^{43}$

Os líquidos iônicos foram empregados apenas recentemente como solventes para a hidrogenação de biocombustíveis e olefinas. Jairton Dupont, Paulo A. Z. Suarez, Myller S. Carvalho e David M. M. Pinho são quatro dos principais colaboradores nesta área ainda pouco estudada. $O$ objetivo da hidrogenação é principalmente 0 melhoramento das características físico-químicas dos combustíveis, e para isto, diversos catalisadores são estudados.

Jairton Dupont, Paulo A. Z. Suarez e colaboradores estudaram a hidrogenação de ciclohexeno em meio com diversos líquidos iônicos e catalisador de Wilkinson, obtendo taxas de conversão de 40 a $65 \%$ em suas reações, onde os líquidos iônicos retém quase por completo o catalisador (98\%), possibilitando a separação do produto por uma simples decantação. ${ }^{36}$ Mesmo não tendo sido desenvolvida a hidrogenação de combustíveis propriamente, este estudo mostrou o alto potencial na recuperação de catalisadores dos meios reacionais assim como a eficiência no emprego como solvente na hidrogenação de olefinas.

Myller S. Carvalho e David M. M. Pinho realizaram pesquisas de hidrogenação de biodiesel, com líquidos iônicos e catalisadores platínicos, visando o melhoramento do biodiesel gerado e aumentando sua estabilidade oxidativa em mais de $20 \mathrm{~h}$ pelo método ASTM D-6751. Os resultados obtidos por ambos mostraram a grande vantagem na recuperação dos catalisadores, seletividade nos produtos formados, bons rendimentos e possibilidade de reciclo do catalisador e do líquido iônico. ${ }^{20,21}$

Ainda são necessários mais estudos da hidrogenação seletiva com o emprego de líquidos iônicos, pois mesmo sendo solventes ecologicamente corretos. ${ }^{21}$ possuírem diversas propriedades físico químicas ${ }^{44}$ e serem seletivos na solubilização de reagentes e produtos ${ }^{20}$, os líquidos iônicos ainda são caros e o seu uso em larga escala ainda não foi devidamente estudado para a produção de biocombustíveis.

Outro problema relacionado ao foco em metodologias de melhoramento de biodiesel ou mesmo na produção deste é a restrição a apenas uma alternativa de biocombustível, fazendo com que haja grande demanda deste produto e, 
consequentemente, de seus reagentes. Por isso é importante que sejam estudados e aprimorados métodos alternativos para a obtenção de biocombustíveis. Um dos principais métodos para a obtenção de biocombustíveis, muito utilizado industrialmente e com grande versatilidade com relação aos reagentes, é o craqueamento térmico e o hidrocraqueamento.

\subsection{Catalisadores Platínicos}

O uso de catalisadores platínicos é muito comum na hidrogenação, empregando principalmente $\mathrm{Pd}, \mathrm{Pt}, \mathrm{Rh}$ e $\mathrm{Ru}$ e é conhecida a atividade destes catalisadores para hidrogenação de ligações $\mathrm{C}=\mathrm{C}$ e $\mathrm{C}=\mathrm{O}{ }^{45}$, 46 Para o hidrocraqueamento 0 uso de catalisadores platínicos vem sendo estudado com diversos metais nos últimos anos tendo em vista o potencial destes. ${ }^{26}$

Recentemente foram desenvolvidos alguns estudos visando a hidrogenação seletiva com o emprego de catalisadores platínicos. Nestes estudos há bons resultados na melhora da seletividade dos produtos formados quando comparados com os catalisadores tradicionais, e uma das propostas é a aplicação na síntese de combustíveis de maior qualidade e estabilidade.

B. S. Souza et al. investigaram o uso de catalisadores de $\mathrm{Pd} / \mathrm{C}$, que é um catalisador comercial largamente vendido e utilizado na hidrogenação, e Pd/ImS3$12 @ \mathrm{Al}_{2} \mathrm{O}_{3}$, que é um catalisador de Paládio nanoparticulado em um meio de surfactante estabilizante zwiteriônico. Para tanto, empregaram reações e hidrogenação de biodiesel com e sem líquidos iônicos e avaliaram os resultados. ${ }^{20}$

Neste estudo as reações de hidrogenação sem líquidos iônicos apresentaram uma maior atividade do catalisador Pd/ImS3-12@ $\mathrm{Al}_{2} \mathrm{O}_{3}$ quando comparado com o Pd/C em função de o Pd/ImS3-12@ $\mathrm{Al}_{2} \mathrm{O}_{3}$ ser preparado a partir de nanopartículas de $\mathrm{Pd}$ em suporte de alumina, além disso o surfactante iônico empregado neste estudo ajuda na dispersão deste catalisador. ${ }^{20} \mathrm{Na}$ Tabela 5 , a seguir, esses resultados podem ser observados. 
Tabela 5: Hidrogenação de biodiesel com diferentes catalisadores ${ }^{a}$. Adaptada de Souza $2012 .^{20}$

\begin{tabular}{|c|c|c|c|c|c|c|}
\hline Amostra & Catalisador & 18:2cis & $18: 2^{\prime b}$ & 18:1cis & 18:1trans & $18: 0$ \\
\hline $0^{c}$ & -- & 58 & 0 & 24 & 0 & 3 \\
\hline 1 & 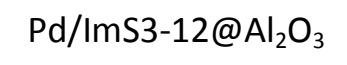 & 0 & 0 & 0 & 0 & 84 \\
\hline 2 & $\mathrm{Pd} / \mathrm{C} 5 \%$ & 22 & 1 & 8 & 16 & 40 \\
\hline
\end{tabular}

Nas reações com o uso do líquido iônico $\mathrm{BMI} \cdot \mathrm{NTf}_{2}$ há um grande aumento da seletividade para a formação de 18:1 cis o que é explicado por B. S. Souza et al. ser em função da maior solubilidade de compostos poli-insaturados quando comparados com o oleato de metila $(18: 1 \mathrm{cis}) .{ }^{20} \mathrm{Em}$ teses de mestrado, David Pinho e Myller Carvalho também estudaram estas reações em condições similares, com diferentes líquidos iônicos mostrando também a influência da solubilidade de ésteres em solventes iônicos para a seletividade de produtos de hidrogenação. ${ }^{12,31,20} \mathrm{Na}$ Tabela 6 abaixo é possível ver a influência do solvente iônico na seletividade quando comparado com as reações sem o uso de líquido iônico. ${ }^{20}$

Tabela 6: Hidrogenação de biodiesel com solvente iônico ${ }^{a}$. Adaptada de B. S. Souza et al. $^{20}$

\begin{tabular}{ccccccccc}
\hline Amostra & $\mathbf{T}^{\mathbf{b}}$ & $\mathbf{p}^{\text {c }}$ & Solvente & $\mathbf{1 8 : 2 c i s}$ & $\mathbf{1 8 : 2}$ & $\mathbf{1 8 : 1 c i s}$ & $\mathbf{1 8 : 1 t}$ & $\mathbf{1 8 : 0}$ \\
\hline $\mathbf{6}$ & 27 & 30 & nenhum & 1 & 0 & 8 & 32 & 50 \\
$\mathbf{7}$ & 27 & 30 & $\mathrm{Li}^{\mathrm{d}}$ & 9 & 9 & 46 & 19 & 8 \\
$\mathbf{1 0}$ & 60 & 30 & nenhum & 0 & 0 & 5 & 17 & 69 \\
$\mathbf{1 1}$ & 60 & 30 & $\mathrm{Li}^{\mathrm{d}}$ & 1 & 2 & 21 & 38 & 29 \\
$\mathbf{1 3}$ & 80 & 30 & $\mathrm{Li}^{\mathrm{d}}$ & 1 & 4 & 17 & 41 & 28
\end{tabular}

$\bar{a} 6 \mathrm{~mL}$ de biodiesel, $1.3 \mu \mathrm{mol}$ de $\mathrm{Pd}, 4 \mathrm{~h} ;{ }^{\mathrm{b}}$ Temperatura ${ }^{\circ} \mathrm{C} ;{ }^{\mathrm{c}}$ Pressão (atm); ${ }^{\mathrm{d}} 1 \mathrm{~mL}$ de BMI.NTf ${ }_{2}$

Poucos estudos foram produzidos no hidroprocessamento de óleos e gorduras vegetais com catalisadores platínicos. 
Um destes raros estudos mostraram que utilizando catalisadores de Rh e Ru em suportes magnéticos, do tipo core-shell, foram obtidos produtos com índice de acidez bem menor que os obtidos por craqueamento térmico, mostrando a atividade destes catalisadores para reações de hidrocraqueamento e hidrodesoxigenação de óleos vegetais. É possível notar alguns resultados obtidos neste estudo na Tabela 7 abaixo.

Tabela 7: Hidrocraqueamento de óleos de mamona e soja na presença de $\mathrm{Fe}_{3} \mathrm{O}_{4} @ \mathrm{SiO}_{2} \mathrm{NH}_{2} \mathrm{Rh}$ sob diferentes condições ${ }^{\text {a }}$. Adaptada de Rodrigues et al. (2014). ${ }^{26}$

\begin{tabular}{|c|c|c|c|c|}
\hline Amostra & Óleo & Massa de Catalisador $/ \%$ & $\mathrm{p} \mathrm{H}_{2} / \mathrm{atm}$ & $\mathrm{IA}^{\mathrm{c}} /\left(\mathbf{m g}_{\text {кон }} \mathbf{g}_{\text {amostra }}{ }^{-1}\right)$ \\
\hline 3 & Mamona & 1 & 25 & 83,20 \\
\hline 4 & Mamona & 0 & 25 & 95,00 \\
\hline 5 & Soja & 1 & 25 & 42,90 \\
\hline 6 & Soja & 0 & 25 & 88,90 \\
\hline
\end{tabular}

${ }^{a}$ Temperatura das reações $=400{ }^{\circ} \mathrm{C} ;{ }^{b} 10 \mathrm{~g}$ de óleo e $0,1 \mathrm{~g}$ de catalisador $(1,5 \mathrm{mg} \mathrm{Rh}) ;{ }^{\circ} \mathrm{IA}=$ índice de acidez.

O emprego de catalisador platínico em suporte magnético nas condições acima especificadas mostraram uma redução de mais da metade no índice de acidez no caso do óleo de soja. No caso do óleo de mamona a acidez persiste mesmo no processo de hidrotratamento com o catalisador de Rh em função da grande quantidade de ácidos graxos com grupo hidroxila provindos do ácido ricinoleico, predominante no óleo de mamona. Grupos oxigenados como os grupos hidroxila aumentam o índice de acidez dos compostos tratados termicamente, diminuindo sensivelmente a atividade dos catalisadores para a desoxigenação e diminuição da acidez. A recuperação dos catalisadores foi feita aplicando-se um campo magnético e não foi necessário o uso de outros métodos como filtragem ou centrifugação. ${ }^{26}$

Os catalisadores magnéticos do tipo core-shell com sílica mesoporosa vem atraindo bastante a atenção dos pesquisadores da catálise pela facilidade de recuperação, vasta possibilidade de aplicações e pela área superficial aumentada que fazem com que este catalisador seja uma excelente opção em diversas situações. 
Partículas do tipo core-shell são feitos a partir de um núcleo (core) revestido por uma casca (shell), esta normalmente servirá de suporte para metais catalisadores ou mesmo servira como peneira molecular. Com isto, as partículas do tipo core-shell tem aplicabilidades como na cromatografia, medicina, catálise e outras áreas.

A fabricação de esferas nanoporosas de diâmetros e porosidades controladas vêm sendo um desafio para a fabricação de suportes do tipo core-shell magnéticos, visto que o tamanho dos poros influencia na impregnação de catalisadores e influencia também na seleção dos reagentes que entrarão em contato com os sítios catalíticos.

No estudo de Atabaev et al. (2013), foram obtidas nanopartículas mesoporosas do tipo core-shell para fins medicinais e foi conseguido um ótimo controle do tamanho das partículas e também dos poros que variaram em torno de $70-75 \mathrm{~nm}$ e 9,4 nm respectivamente. ${ }^{35}$

Jacinto et al. (2015) sintetizaram catalisadores de Pt em suportes do tipo coreshell de $\mathrm{Fe}_{3} \mathrm{O}_{4}$ em $\mathrm{SiO}_{2}$ mesoporosa. Conforme usual nas publicações envolvendo materiais do tipo core-shell, estes catalisadores são referidos como $\mathrm{Fe}_{3} \mathrm{O}_{4} @ \mathrm{SiO}_{2} @ \mathrm{Pt}$, onde o símbolo "@" significa que a platina esta depositada sobre a sílica, que esta depositada sobre a magnetita $\left(\mathrm{Fe}_{3} \mathrm{O}_{4}\right)$. Os poros destes catalisadores tiveram dimensões controladas entre 2,4 a 4,1 nm e o tamanho das partículas de Platina também foram controlados entre 2 e $4 \mathrm{~nm}^{47}$

Estes catalisadores foram testados para a redução do antraceno em condições amenas, com temperatura de $30{ }^{\circ} \mathrm{C}, 1,5$ atm de $\mathrm{H}_{2}$ e $60 \mathrm{~min}$, onde foi obtida uma redução quase completa do antraceno, mostrando resultados nunca antes obtidos na literatura. Testes de lixiviação também mostraram resultados promissores, com menos de 0,01 ppm (menor que o limite de detecção) de perda de catalisador por reação (análises feitas por ICP-OES). ${ }^{47}$

A sílica mesoporosa aumenta muito a área superficial do catalisador quando comparado com materiais não porosos, podendo aumentar a atividade do catalisador e também podendo atuar como um tipo de peneira molecular, já que a dimensão dos poros pode ser facilmente controlada.

Neste trabalho serão estudadas a propriedades desses catalisadores platínicos em suportes nanoporosos do tipo core-shell para o melhoramento de combustíveis por meio de reações de hidrogenação seletiva de biodiesel. 
MATERIAIS E MÉTODOS 


\section{Materiais e Métodos}

\subsection{Reagentes}

Para a síntese do biodiesel foram utilizados: óleo de soja refinado da marca LIZA, hidróxido de potássio $(\mathrm{KOH})$, ácido sulfúrico $\left(\mathrm{H}_{2} \mathrm{SO}_{4}\right)$ e metanol da marca VETEC Química Fina.

Para a preparação dos líquidos iônicos foram separados metilimidazol 97 \% e $\mathrm{NaBF}_{4} 98 \%$ da Acros Organic,sulfato de magnésio, $n$-butanol 99,4 \% e trietilamina 99,5\% da VETEC Química Fina LTDA, cloreto de metanossulfonila $98 \%$ foi obtido da Alfa Aesar, o $n$-metilimidazol , o tetraborato de sódio e o trifluorometanosulfonilimidato de lítio foram obtidos da Aldrich.

Os gases utilizados para as análises cromatográficas e para as reações de hidrogenação foram hélio e o hidrogênio (respectivamente), ambos de grau analítico, obtidos da White Martins.

Para as análises de cromatografia líquida de alta eficiência foram utilizados os solventes acetonitrila, álcool isopropílico, hexano, e metanol, todos de grau UVespectroscópico da marca VETEC Química Fina.

Para as análises de infravermelho foram utilizados os solventes ciclohexano e acetato de etila da marca VETEC Química Fina.

\subsection{Sínteses Orgânicas}

\subsubsection{Síntese do ésteres metílicos}

O biodiesel de soja foi produzido pela transesterificação com catalisador básico $(\mathrm{KOH})$. Primeiramente foi preparada uma dissolução de $1 \mathrm{~g}$ de $\mathrm{KOH}$ em $40 \mathrm{~mL}$ de metanol. Em seguida esta solução foi adicionada em um balão de fundo redondo contendo $100 \mathrm{~mL}$ de óleo de soja previamente seco em vácuo. Foi então montado um sistema de refluxo e mistura foi deixada sob agitação vigorosa por $2 \mathrm{~h}$ à temperatura ambiente. A glicerina (subproduto da reação) foi retirada com um funil de separação e 
neste funil o biodiesel foi lavado 3 vezes com uma solução $0,5 \% \mathrm{v} / \mathrm{v}$ de $\mathrm{H}_{2} \mathrm{SO}_{4}$ para neutralização do catalisador e em seguida lavado com água morna diversas vezes ate que a água de lavagem estivesse translúcida. O biodiesel resultante foi posto para reagir novamente como descrito no início desta síntese a fim de se obter uma maior pureza do produto. Após estes procedimentos o biodiesel foi seco em vácuo e armazenado em refrigerador a uma temperatura de $0^{\circ} \mathrm{C}$.

Esta síntese foi baseada no trabalho de Carvalho, M. S. (2008). ${ }^{12}$

\subsubsection{Síntese dos líquidos iônicos}

Síntese do Líquido lônico $\left(\mathrm{BMI}^{\mathrm{B} F}{ }_{4}\right)$ tetrafluoroborato de 1-n-butil-3-metilimidazólio

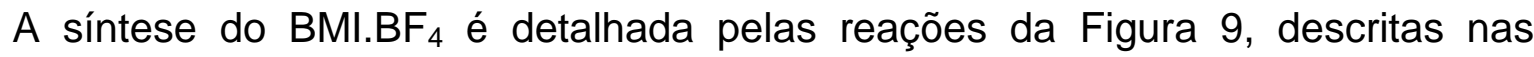
etapas adaptadas de Cassol et al. (2006). ${ }^{48}$

(a) $\mathrm{MeSO}_{2} \mathrm{Cl} \underset{\mathrm{NEt}_{3}}{\stackrel{\mathrm{BuOH}}{\longrightarrow}} \mathrm{MeSO}_{3} \mathrm{Bu}(\mathrm{l})+\mathrm{Et} 3 \mathrm{NHCl}(\mathrm{s})$

(b)

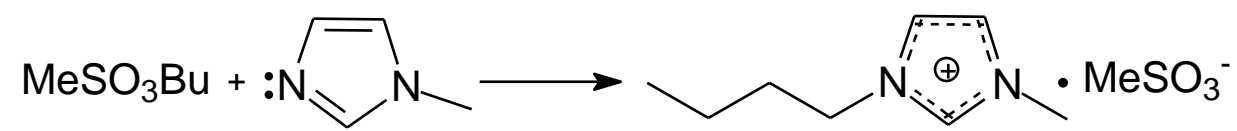

$\mathrm{BMI} . \mathrm{MeSO}_{3}$

(c)

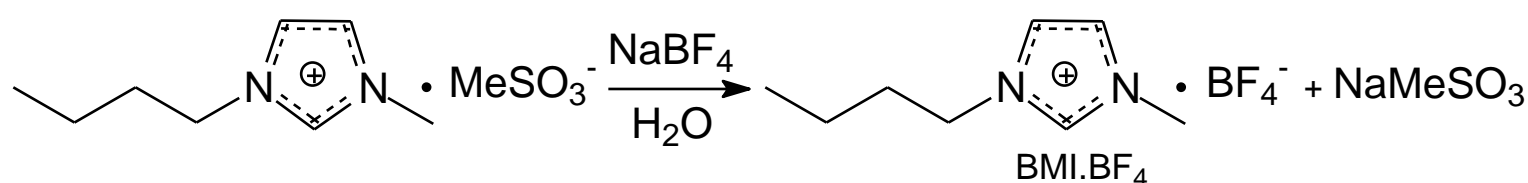

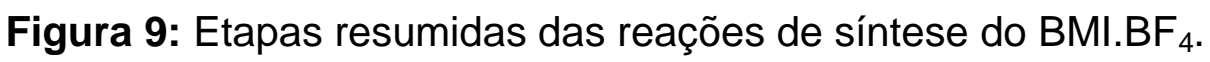

O procedimento é detalhado nas etapas a, b e c.

\section{a) Preparação do butilmetanosulfonila}

A massa de 183,20 $\mathrm{g}$ de cloreto de metanossulfonila ( $1,60 \mathrm{~mol}$ ) foi gotejada sob agitação vigorosa a uma solução de $n$-butanol (118,40 g), trietilamina $(161,60 \mathrm{~g})$ e diclorometano $(1,50 \mathrm{~L})$ a $5^{\circ} \mathrm{C}$. Em seguida, a reação foi submetida a agitação média por 
2 h. Após a reação o cloreto de trietilamônio foi extraído com $300 \mathrm{~mL}$ de água ultrapura. A fase orgânica foi lavada com água ultrapura e o produto obtido foi seco e destilado sob pressão reduzida. A butilmetanosulfonila foi reagida com mais $70 \mathrm{~mL}$ de $n$-butanol e 110 $\mathrm{mL}$ de trietilamina por $24 \mathrm{~h}$. O produto final, a butilmetanossulfonila foi destilada sob pressão reduzida produzindo um líquido translúcido e incolor.

\section{b) Preparação do metanosulfonato de 1-n-butil-3-metil-imidazólio $\left(\mathrm{BMI}^{\mathrm{MeSO}} \mathrm{S}_{3}\right)$}

O produto da etapa a $(241,90 \mathrm{~g})$ foi reagido com $130,50 \mathrm{~g}$ de metilimidazol por 24 h e $27^{\circ} \mathrm{C}$. A solução resultante foi vagarosamente gotejada em acetato de etila com

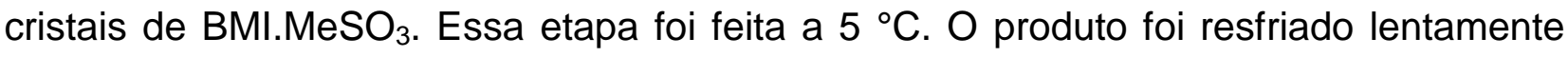
por $24 \mathrm{~h}$ e os cristais foram lavados com acetato de etila até $\mathrm{opH}$ estar levemente acidificado. $\mathrm{O} \mathrm{BMI.} \mathrm{MeSO}_{3}$ foi seco sob pressão reduzida formando cristais brancos.

\section{c) Preparação do tetrafluoroborato de 1-n-butil-3-metil-imidazólio $\left(\mathrm{BMI}^{\left.-B_{4}\right)}\right.$}

$82 \mathrm{~g}$ dos cristais de $\mathrm{BMI}^{\mathrm{MeSO}} \mathrm{S}_{3}$ foram misturados a $42,5 \mathrm{~g}$ de tetrafluoroborato de sódio e $75 \mathrm{~mL}$ de água em balão de fundo redondo e deixados sob agitação vigorosa por $30 \mathrm{~min}$. A fase orgânica foi separada em funil e seca sob pressão reduzida. Após tratamento com $\mathrm{MgSO}_{4}$ anidro, filtração a vácuo e secagem sob pressão reduzida por 24 h, o líquido iônico BMI.BF 4 foi purificado sendo levemente viscoso, translúcido.

\section{Síntese do Líquido lônico bis-(trifluorometilsulfonil)imida de 1-N-butil-3- $N$ - metilimidazólio (BMI.NTf ${ }_{2}$ )}

A síntese do (BMI.NTf 2 necessita de duas etapas. Na primeira 1,85 mol de $\mathrm{N}$ metilimidazol é misturado a $2,5 \mathrm{~mol}$ de clorobutano e a mistura mantida sob agitação média a $80{ }^{\circ} \mathrm{C}$ durante dois dias em sistema de condensação. $\mathrm{O}$ clorobutano em excesso é retirado do produto por meio de rota-evaporação. Após purificado, o produto é diluído em acetato de etila, onde surgem cristais. Estes cristais de cloreto de 1-N-butil-3$\mathrm{N}$-metilimidazol (BMI.Cl) passam por várias recristalizações em acetona para purificação. 
Após a primeira etapa $1,65 \mathrm{~mol}$ do cloreto de 1 - $N$-butil-3- $N$-metilimidazol (BMI.Cl) é adicionado a uma solução aquosa de trifluorometanosulfonilimidato de lítio $\left(\mathrm{LiNTf}_{2}\right)$ e a mistura mantida sob agitação por $1 \mathrm{~h}$. O produto é separado em funil de separação. $\mathrm{O}$ produto é então filtrado em coluna com alumina básica e celite e posteriormente seco sob pressão reduzida, gerando o líquido iônico translucido e viscoso BMI.NTf 2 .

As sínteses mostradas para o BMI.BF 4 e BMI.NTf $f_{2}$ foram baseadas no trabalho de Cassol et al. (2006). ${ }^{48}$

\subsection{Catalisadores Magnéticos ${ }^{47}$}

Os catalisadores utilizados neste trabalho foram o $\mathrm{Fe}_{3} \mathrm{O}_{4} @ \mathrm{mSiO} \mathrm{S}_{2} @ \mathrm{Pt} \mathrm{e}$ $\mathrm{Fe}_{3} \mathrm{O}_{4} @ \mathrm{mSiO} \mathrm{O}_{2} @ \mathrm{Pt} / \mathrm{Pd}$, com teores de metais de 1,6\% para o primeiro, 0,49\% e 0,6\% para 0 catalisador bimetálico, estes teores foram medidos por ICP-OES. ${ }^{47}$ Os catalisadores foram fornecidos por Jacinto e colaboradores e a síntese destes catalisadores está descrita no trabalho de Jacinto et al. (2015). ${ }^{47}$

\subsection{Reações}

\subsubsection{Reações de Hidrogenação}

As reações de hidrogenação de biodiesel foram realizadas em reator de aço inox com recipiente de reação (copo) em vidro e hermeticamente fechado e vedado por anel de teflon. O reator possui manômetro para controle da pressão, dedo frio para controle de temperatura e válvula para entrada e liberação de pressão.

Em todas as reações de hidrogenação primeiramente o catalisador é pesado no copo de vidro do reator (este previamente tarado) e a massa de catalisador é anotada.

Para as reações sem líquidos iônicos, o biodiesel é adicionado em seguida ao catalisador e o sistema é montado e pressurizado para a reação.

Nas reações de reciclo, de estudo do tempo e reações com líquidos iônicos o sistema reacional é preparado e fechado e, quando desejado, alíquotas de amostra (produto hidrogenado) são retiradas com micropipeta (19 mg) e em seguida o sistema reacional é novamente pressurizado e aquecido para continuidade das reações. Nas 
reações de reciclos os catalisadores foram lavados com solvente ciclohexano e os catalisadores foram separados com auxílio de um imã de neodímio de $4500 \mathrm{G}$, então o recipiente e pesado para verificação da massa de catalisador. Este procedimento foi realizado para a retirada de produtos hidrogenados do sistema reacional.

No caso das reações com líquido iônico, este é adicionado em seguida ao catalisador também no copo de vidro do reator e a massa é anotada. Seguindo, o copo é colocado dentro do reator e este é fechado e pressurizado com $\mathrm{N}_{2}$, o sistema é então posto sob agitação para dispersão do catalisador no líquido iônico durante $10 \mathrm{~min}$. Em seguida o sistema é aberto e é inserido no copo do reator a massa de biodiesel desejada para que então o reator seja montado e pressurizado com gás hidrogênio.

A pressão durante a reação é monitorada pelo manômetro enquanto a temperatura e a agitação são mantidas por uma placa de aquecimento.

$\mathrm{Na}$ tabela 8 são expostas as variações nas condições reacionais das reações de hidrogenação com e sem líquidos iônicos com catalisadores de Pt e Pt/Pd.

Tabela 8: Condições reacionais de reações de hidrogenação de biodiesel

\begin{tabular}{|c|c|c|c|c|c|c|}
\hline Catalisadores & $\begin{array}{c}\text { Massa de } \\
\text { Catalisador (g) }\end{array}$ & $\begin{array}{c}\text { Pressão } \\
\text { (atm) }\end{array}$ & $\begin{array}{c}\text { Temperatur } \\
\text { a }\left({ }^{0} \mathrm{C}\right)\end{array}$ & $\begin{array}{c}\text { Tempo } \\
\text { (h) }\end{array}$ & Recíclo & $\begin{array}{l}\text { Líquidos } \\
\text { lônicos }\end{array}$ \\
\hline $\mathrm{Pt}$ & 0,$01 ; 0,025 ; 0,05 ; 0,1$ & \multirow{2}{*}{12,5} & \multirow{2}{*}{60} & \multirow{2}{*}{2} & & \\
\hline $\mathrm{Pt} / \mathrm{Pd}$ & 0,$01 ; 0,034 ; 0,05 ; 0,1$ & & & & & \\
\hline $\mathrm{Pt}$ & 0,025 & \multirow{2}{*}{$\begin{array}{l}12,5 ; 50 \\
75\end{array}$} & \multirow{2}{*}{60} & \multirow{2}{*}{2} & & \\
\hline $\mathrm{Pt} / \mathrm{Pd}$ & 0,034 & & & & & \\
\hline $\mathrm{Pt}$ & 0,025 & \multirow{2}{*}{12,5} & \multirow{2}{*}{27,$5 ; 60 ; 120$} & \multirow{2}{*}{2} & & \\
\hline $\mathrm{Pt} / \mathrm{Pd}$ & 0,034 & & & & & \\
\hline $\begin{array}{c}\mathrm{Pt} \\
\mathrm{Pt} / \mathrm{Pd}\end{array}$ & 0,1 & 12,5 & 60 & $2 ; 4 ; 6 ; 14$ & & \\
\hline $\begin{array}{c}\mathrm{Pt} \\
\mathrm{Pt} / \mathrm{Pd}\end{array}$ & 0,1 & 12,5 & 60 & 2 & $\begin{array}{c}1 ; 2 ; 3 ; 4 ; \\
5\end{array}$ & \\
\hline $\mathrm{Pt}$ & 0,025 & \multirow{2}{*}{75} & \multirow{2}{*}{60} & \multirow{2}{*}{$2 ; 4 ; 6 ; 14$} & & \multirow{2}{*}{$\mathrm{BMI} \mathrm{BF}_{4}$} \\
\hline $\mathrm{Pt} / \mathrm{Pd}$ & 0,034 & & & & & \\
\hline $\mathrm{Pt}$ & 0,025 & \multirow{2}{*}{75} & \multirow{2}{*}{60} & \multirow{2}{*}{$2 ; 4 ; 6 ; 14$} & & \multirow{2}{*}{ BMI.NTf ${ }_{2}$} \\
\hline $\mathrm{Pt} / \mathrm{Pd}$ & 0,034 & & & & & \\
\hline
\end{tabular}




\subsection{Análises Químicas e Físico-Químicas}

\subsubsection{Cromatografia Líquida de Alta Eficiência (CLAE)}

A cromatografia líquida foi utilizada para a separação dos diferentes ésteres do biodiesel para quantificação dos mesmo e verificação das taxas de hidrogenação do biodiesel.

A cromatografia foi realizada em um cromatógrafo Shimadzu CTO-20A com detector de ultravioleta. $O$ volume de injeção foi de $10 \mu \mathrm{L}$, fluxo de solvente de $1 \mathrm{~mL} \mathrm{~min}$ 1, a coluna empregada foi a Shim-Pack VP-ODS (C18, $250 \mathrm{~mm}$ de comprimento e 4,6 $\mathrm{mm}$ de diâmetro), foram montadas duas colunas em sequência para melhor separação dos ésteres. A temperatura para esta análise foi mantida a $40{ }^{\circ} \mathrm{C}$ no forno e o detector de UV foi configurado para o comprimento de onda de $205 \mathrm{~nm}$. O eluente empregado foi a acetonitrila.

O preparo das amostras para a injeção foi: $20 \mu \mathrm{L}$ de amostra dissolvidos em 20 $\mathrm{mL}$ de acetonitrila.

Nesta análise o teor de palmitato de metila (8\%) de todas as reações foi ocultado.

Esta metodologia foi desenvolvida e reportada previamente na literatura. ${ }^{12,49}$

\subsubsection{Estabilidade Oxidativa}

A análise de estabilidade oxidativa foi feita seguindo os procedimentos descritos na metodologia EN 15751 e EN 14112 (accelerated oxidation test), da European Committee for Standards (ESC) de 2003. A temperatura de análise foi $110{ }^{\circ} \mathrm{C}$ e a análise foi interrompida assim que a condutividade atingisse $200 \mu \mathrm{S} / \mathrm{cm}$.

O equipamento utilizado para esta análise foi o Metrohm 837 Biodiesel Rancimat.

\subsubsection{Viscosidade e Densidade}

As análises de viscosidade e densidade foram realizadas no equipamento Anton Paar Stabinger Viscometer SVM 3000 que realizou as medidas de viscosidade e densidade simultaneamente. 
As medidas de viscosidade e densidade foram realizadas à temperatura de $45^{\circ} \mathrm{C}$, todas em triplicata.

\subsubsection{Microscopia Eletrônica de Varredura (MEV)}

As imagens de microscopia eletrônica de varredura foram geradas em um equipamento JSM-7100F (Field Emission Scanning Electron Microscope) da marca JEOL e a voltagem empregada nas análises foi de $20 \mathrm{kV}$. As amostras foram secas e preparadas com fita metalizadora para melhor resolução das imagens.

\subsubsection{Calorimetria Exploratória Diferencial (CED)}

Nesta análise, foi verificada a variação de energia e mudanças de fases (detectadas por variações na temperatura em função do tempo) da amostra. Para tanto, a amostra e a referência são dispostas em um forno que analisará a variação de temperatura destas amostras pela energia aplicada pelo forno.

Para a análise das amostras de biodiesel e biodiesel hidrogenado, foi feita uma análise de $-50{ }^{\circ} \mathrm{C}$ a $50{ }^{\circ} \mathrm{C}$ com a variação de $5^{\circ} \mathrm{C}$ por min, e fluxo de nitrogênio de 30 $\mathrm{mL} / \mathrm{min}$. A referência utilizada foi uma um cadinho de alumínio vazio.

O equipamento utilizado nesta análise foi um Shimadzu DSC-60, com resfriamento por nitrogênio líquido. 
RESULTADOS E DISCUSSÃO 


\section{Resultados e Discussão}

\subsection{Reações de Hidrogenação do Biodiesel de Soja}

\subsubsection{Estudo da proporção (catalisador : biodiesel) ideal}

As reações de hidrogenação de biodiesel de soja foram feitas visando a diminuição das cadeias poli-insaturadas, formando cadeias com uma insaturação na posição cis. Como já descrito, o objetivo desta reação é o aumento da estabilidade oxidativa, sem influenciar muito no ponto de fusão do combustível.

O primeiro passo para o estudo da atividade dos catalisadores de $\mathrm{Fe}_{3} \mathrm{O}_{4} @ \mathrm{mSiO}{ }_{2} @ \mathrm{Pt}$ e $\mathrm{Fe}_{3} \mathrm{O}_{4} @ \mathrm{mSiO}{ }_{2} @ \mathrm{Pt} / \mathrm{Pd}$ foi a realização de reações com temperatura, tempo e pressão fixas e variando a massa de catalisador, a fim de verificar qual a quantidade ótima de catalisador para uma determinada quantidade de ésteres metílicos.

As condições escolhidas para esta etapa foram: $10 \mathrm{~g}$ de biodiesel, 12,5 atm de $\mathrm{H}_{2}$, $60{ }^{\circ} \mathrm{C}$ e $2 \mathrm{~h}$ de reação, sob constante agitação. Os resultados obtidos por cromatografia líquida de alta eficiência (CLAE) com um detector de UV, que determinou os teores em porcentagem em massas dos ésteres metílicos das reações com o catalisador de $\mathrm{Pt}$ podem ser verificados na Tabela 9 abaixo.

Tabela 9: Porcentagens dos ésteres metílicos de soja hidrogenados com diferentes massas de catalisador de Pt.

\begin{tabular}{cccccccccc}
\hline \multicolumn{8}{c}{ Reações Variando a Massa de Catalisador de Pt } \\
\hline $\begin{array}{c}\text { Massa de } \\
\text { catalisador } \\
(\mathbf{g})\end{array}$ & Reação & $\mathbf{1 8 : 3 c i s}$ & $\mathbf{1 8 : 2 c i s}$ & $\mathbf{1 8 : 2}$ & $\mathbf{1 8 : 1 \text { cis }}$ & $\mathbf{1 8 : 1 t}$ & $\mathbf{1 8 : 0 0}$ & TOTAL \\
\hline & Biodiesel & 7 & 52 & 0 & 26 & 0 & 7 & 100 \\
Branco & Branco & 7 & 52 & 0 & 26 & 0 & 7 & 100 \\
0,01 & 1 & 6 & 59 & 0 & 21 & 0 & 6 & 100 \\
0,025 & 2 & 3 & 49 & 0 & 31 & 0 & 9 & 100 \\
0,05 & 3 & 2 & 46 & 0 & 31 & 0 & 13 & 100 \\
0,1 & 4 & 0 & 10 & 0 & 53 & 0 & 28 & 100 \\
\hline
\end{tabular}


A massa de catalisador de Pt influencia muito na formação de produtos hidrogenados. Esta conclusão pode ser explicada pelo fato de quanto mais catalisador disperso no meio, mais facilmente o hidrogênio entrará em contato com um sítio catalítico e mais facilmente ocorrerá a hidrogenação do biodiesel.

É possível notar que a massa de $0,1 \mathrm{~g}$ de catalisador de Platina proporcionou ótimas conversões com ótima seletividade para o oleato de metila (produto almejado), porém esta quantidade de catalisador $(1 \% \mathrm{~m} / \mathrm{m})$ além de ser uma razão que provavelmente não será usada na indústria em função do alto custo do catalisador em relação ao produto, é uma massa muito alta para a quantidade de catalisador disponível e aumentaria muito os custos deste estudo, outro fator é o produto obtido ser sólido à temperatura ambiente $\left(27^{\circ} \mathrm{C}\right)$. Então, foi selecionada como melhor massa de catalisador a reação $2 \mathrm{com} 0,025 \mathrm{~g}$ de catalisador para as reações, pois esta reação obteve os melhores resultados de hidrogenação em função da massa de catalisador empregada.

Em seguida, e com o mesmo objetivo, foi feito o estudo da melhor razão entre massa de catalisador para uma determinada quantidade de biodiesel de soja para o catalisador de $\mathrm{Fe}_{3} \mathrm{O}_{4} @ \mathrm{mSiO}{ }_{2} @ \mathrm{Pt} / \mathrm{Pd}$ (catalisador de Pt/Pd), sob as mesmas condições reacionais das reações 1 a 4 citadas anteriormente. Os resultados cromatográficos das reações podem ser verificados na Tabela 10 a seguir.

Tabela 10: Porcentagens dos ésteres metílicos de soja hidrogenados com diferentes massas de catalisador de $\mathrm{Pt} / \mathrm{Pd}$.

\begin{tabular}{cccccccccc}
\hline \multicolumn{8}{c}{ Reações Variando o Catalisador de Pt/Pd } \\
\hline $\begin{array}{c}\text { Massa de } \\
\text { catalisador } \\
(\mathbf{g})\end{array}$ & Reação & $\mathbf{1 8 : 3 c i s}$ & $\mathbf{1 8 : 2 c i s}$ & $\mathbf{1 8 : 2}$ & $\mathbf{1 8 : 1 c i s}$ & $\mathbf{1 8 : 1 t}$ & $\mathbf{1 8 : 0}$ & TOTAL \\
\hline Branco & Biodiesel & 7 & 52 & 0 & 26 & 0 & 7 & 100 \\
0,01 & Branco & 7 & 52 & 0 & 26 & 0 & 7 & 100 \\
0,034 & 5 & 4 & 47 & 0 & 30 & 0 & 11 & 100 \\
0,05 & 6 & 1 & 6 & 1 & 12 & 40 & 32 & 100 \\
0,1 & 7 & 0 & 2 & 0 & 2 & 34 & 54 & 100 \\
& 8 & 0 & 1 & 0 & 0 & 36 & 53 & 100 \\
\hline
\end{tabular}

A seletividade deste catalisador para a formação de oleato de metila é bem inferior à do catalisador de Pt pura, porém a atividade deste é maior. Isto mostra que a 
seletividade do catalisador de Platina é melhor para a formação de oleato de metila quando comparado com o catalisador bimetálico de $\mathrm{Pt} / \mathrm{Pd}$.

É notável que a reação 5 (com massa de $10 \mathrm{mg}$ de catalisador) não teve uma boa conversão dos reagentes em produtos hidrogenados, quando a massa foi aumentada para $34 \mathrm{mg}$ (reação 6) a conversão aumentou drasticamente, porém formando produtos trans. A formação de compostos 18:1, mesmo que os isômeros trans, é um bom resultado visto que, com o emprego de solventes adequados pode ser controlada e favorecida a formação apenas de isômeros cis.

Outra observação foi que houve um aumento grande na conversão quando a massa foi aumentada de $10 \mathrm{mg}$ para $34 \mathrm{mg}$ de catalisador, e quando foi aumentada mais a massa de catalisador o aumento na conversão foi pequeno, mostrando que foi praticamente alcançado o valor quase ideal de catalisador no meio reacional.

\subsubsection{Estudo da influência da pressão de $\mathrm{H}_{2}$, temperatura e tempo no meio reacional}

A primeira parte da segunda etapa deste trabalho envolveu o estudo da influência da pressão nas reações de hidrogenação. Para tanto foram empregadas as massas escolhidas como ideais e as condições da etapa anterior e aplicou-se diferentes pressões para as reações.

As condições reacionais foram: temperatura de $60{ }^{\circ} \mathrm{C}$, tempo de $2 \mathrm{~h}, 0,025 \mathrm{~g}$ de catalisador de Pt e $0,034 \mathrm{~g}$ de catalisador de $\mathrm{Pt} / \mathrm{Pd}$. Os resultados obtidos por cromatografia podem ser verificados na Tabela 11 apresentada abaixo.

Tabela 11: Porcentagens dos ésteres metílicos de soja hidrogenados com diferentes pressões para o catalisador de Pt.

\begin{tabular}{cccccccccc}
\hline \multicolumn{7}{c}{ Reações Variando Pressão com Catalisador de Pt } \\
\hline $\begin{array}{c}\text { Pressão } \\
\text { (atm) }\end{array}$ & Reação & $\mathbf{1 8 : 3 c i s ~}$ & $\mathbf{1 8 : \mathbf { 3 } ^ { \prime }}$ & $\mathbf{1 8 : 2 c i s}$ & $\mathbf{1 8 : 2}$ & $\mathbf{1 8 : 1 \text { cis }}$ & $\mathbf{1 8 : 1 t}$ & $\mathbf{1 8 : 0 0}$ & TOTAL \\
\hline & Biodiesel & 7 & 0 & 52 & 0 & 26 & 0 & 7 & 100 \\
Branco & Branco & 7 & 0 & 52 & 0 & 26 & 0 & 7 & 100 \\
12,5 & 2 & 3 & 0 & 48 & 0 & 31 & 0 & 9 & 100 \\
50 & 9 & 2 & 0 & 48 & 0 & 32 & 0 & 10 & 100 \\
75 & 10 & 2 & 0 & 46 & 0 & 33 & 0 & 11 & 100 \\
\hline
\end{tabular}


O aumento da pressão (75 atm) não mudou muito a formação de produtos cis quando comparado com a reação 2 onde a pressão foi de 12,5 atm. A mudança de 50 atm (reação 9) para 75 atm não mostrou melhora significativa na hidrogenação. Isto pode ser explicado pelo fato de a cinética da reação não estar sendo limitada pela pressão. Como verificamos na Tabela 9 , um dos fatores limitantes nesta reação é o catalisador. Outros fatores limitantes podem ser a temperatura e o tempo de reação, pois quando há hidrogenação a mistura de ésteres metílicos tende a ficar mais viscosa em consequência da mudança nas angulações das cadeias de ésteres (exemplificadas na Figura 2) e isto faz com que quanto maior a quantidade de ésteres hidrogenados, mais difícil será a hidrogenação dos ésteres restantes em uma dada temperatura, e quanto mais baixa a temperatura, mais viscosa será a mistura de ésteres.

Este mesmo estudo foi feito para o catalisador de $\mathrm{Pt} / \mathrm{Pd}$, e os resultados podem ser verificados na tabela a seguir.

Tabela 12: Porcentagens dos ésteres metílicos de soja hidrogenados com diferentes pressões para o catalisador de $\mathrm{Pt} / \mathrm{Pd}$.

Reações Variando Pressão com Catalisador de Pt/Pd

\begin{tabular}{ccccccccc}
\hline $\begin{array}{c}\text { Pressão } \\
\text { (atm) }\end{array}$ & Reação & $\mathbf{1 8 : 3 c i s}$ & $\mathbf{1 8 : 2 c i s}$ & $\mathbf{1 8 : 2}$ & $\mathbf{1 8 : 1 c i s}$ & $\mathbf{1 8 : 1 t}$ & $\mathbf{1 8 : 0 0}$ & TOTAL \\
\hline & Biodiesel & 7 & 52 & 0 & 26 & 0 & 7 & 100 \\
Branco & Branco & 7 & 52 & 0 & 26 & 0 & 7 & 100 \\
12,5 & 6 & 0 & 6 & 1 & 12 & 40 & 32 & 100 \\
50 & 11 & 0 & 7 & 1 & 11 & 37 & 44 & 100 \\
75 & 12 & 0 & 8 & 0 & 9 & 26 & 49 & 100 \\
\hline
\end{tabular}

É possível notar que o aumento da pressão diminuiu drasticamente a formação de produtos trans, característicos deste catalisador de $\mathrm{Pt} / \mathrm{Pd}$. Este comportamento já foi verificado anteriormente para a hidrogenação de ésteres metílicos por Carvalho et al. (2011), onde foi possível notar que o aumento da pressão aumenta a seletividade isomérica dos produtos formados, principalmente para pressões acima de $50 \mathrm{~atm} .{ }^{21}$

Em comparação com o catalisador de Pt pura, o catalisador de $\mathrm{Pt} / \mathrm{Pd}$ é menos seletivo mesmo com o aumento drástico na pressão de $\mathrm{H}_{2}$, mostrando que este não é um fator predominante para a formação seletiva de produtos. 
Outro estudo desta etapa foi a verificação dos efeitos da temperatura nas reações de hidrogenação. Para tanto, foram feitas reações em três temperaturas diferentes: $30{ }^{\circ} \mathrm{C}, 60^{\circ} \mathrm{C}$ e $120{ }^{\circ} \mathrm{C}$ com condições de pressão, tempo reacional e massa de catalisador fixas e iguais às adotadas nas reações 2 e 6 para os catalisadores de Pt e $\mathrm{Pt} / \mathrm{Pd}$, respectivamente $(0,025 \mathrm{~g}$ e $0,034 \mathrm{~g})$.

Os resultados cromatográficos para as reações variando a temperatura para o catalisador de Pt podem ser conferidas na Tabela 13.

Tabela 13: Porcentagens dos ésteres metílicos de soja hidrogenados com diferentes temperaturas para o catalisador de Pt.

\begin{tabular}{cccccccccc}
\hline \multicolumn{8}{c}{ Reações Variando Temperatura com Catalisador de Pt } \\
\hline $\begin{array}{c}\text { Temp. } \\
{ }^{\circ} \mathbf{C}\end{array}$ & Reação & $\mathbf{1 8 : 3 c i s}$ & $\mathbf{1 8 : 3}$ & $\mathbf{1 8 : 2 c i s}$ & $\mathbf{1 8 : 2}$ & $\mathbf{1 8 : 1 \text { cis }}$ & $\mathbf{1 8 : 1 t}$ & $\mathbf{1 8 : 0 0}$ & TOTAL \\
\hline & Biodiesel & 7 & 0 & 52 & 0 & 26 & 0 & 7 & 100 \\
Branco & Branco & 7 & 0 & 52 & 0 & 26 & 0 & 7 & 100 \\
27.5 & 13 & 7 & 0 & 50 & 0 & 25 & 1 & 9 & 100 \\
60 & 2 & 3 & 0 & 49 & 0 & 31 & 0 & 9 & 100 \\
120 & 14 & 2 & 0 & 41 & 0 & 33 & 0 & 15 & 100 \\
\hline
\end{tabular}

À temperatura ambiente há pouca hidrogenação e é favorecida a formação de isômeros trans, uma possível explicação é a cinética das moléculas (movimentação em função da temperatura), que a baixas temperaturas pode diminuir a probabilidade de haver contatos com o catalisador e com o hidrogênio no meio. Outra possível explicação é a elevada viscosidade dos reagentes que dificulta a permeação de hidrogênio na fase líquida e dificulta assim o contato do hidrogênio com o catalisador. Com isto a quantidade de hidrogênio fica limitada favorecendo a formação de isômeros trans.

Quando a temperatura é aumentada para $60{ }^{\circ} \mathrm{C}$ o gás hidrogênio tem maior pressão e facilidade para permeação na fase líquida, facilitando também o contato com a superfície catalítica. Da mesma forma quando a temperatura é aumentada para $120{ }^{\circ} \mathrm{C}$ a reação tende a ocorrer de forma mais expressiva, porém como a quantidade de hidrogênio é limitada, não há grande desenvolvimento dos produtos hidrogenados, mas mesmo assim a mistura de ésteres final é sólida à temperatura ambiente.

Este estudo também foi repetido para o catalisador de $\mathrm{Pt} / \mathrm{Pd}$ e os resultados podem ser verificados na Tabela 14 a seguir. 
Tabela 14: Porcentagens dos ésteres metílicos de soja hidrogenados com diferentes temperaturas para o catalisador de $\mathrm{Pt} / \mathrm{Pd}$.

\begin{tabular}{cccccccccc}
\hline \multicolumn{7}{c}{ Reações Variando Temperatura com Catalisador de Pt/Pd } \\
\hline $\begin{array}{c}\text { Temp. } \\
{ }^{\circ} \mathbf{C}\end{array}$ & Reação & $\mathbf{1 8 : 3 c i s}$ & $\mathbf{1 8 : 3 t}$ & $\mathbf{1 8 : 2 c i s}$ & $\mathbf{1 8 : 2 t}$ & $\mathbf{1 8 : 1 c i s}$ & $\mathbf{1 8 : 1 t}$ & $\mathbf{1 8 : 0 0}$ & TOTAL \\
\hline & Biodiesel & 7 & 0 & 52 & 0 & 26 & 0 & 7 & 100 \\
Branco & Branco & 7 & 0 & 52 & 0 & 26 & 0 & 7 & 100 \\
27.5 & 15 & 2 & 0 & 19 & 0 & 21 & 25 & 23 & 100 \\
60 & 6 & 0 & 0 & 6 & 1 & 12 & 40 & 32 & 100 \\
120 & 16 & 0 & 0 & 0 & 0 & 2 & 40 & 49 & 100 \\
\hline
\end{tabular}

É possível notar que, diferentemente da reação 13, a reação 15 (temperatura de $27,5{ }^{\circ} \mathrm{C}$ ) ocorreu relativamente mais hidrogenação, porém houve grande formação de produtos 18:1 trans. É verificada novamente uma maior atividade deste catalisador quando comparado com o catalisador de Pt.

Quando a temperatura é aumentada para $60^{\circ} \mathrm{C}$ e $120^{\circ} \mathrm{C}$, notamos um aumento na taxa de hidrogenação e o aumento do produto saturado (estearato de metila) e uma diminuição dos produtos insaturados, principalmente os produtos de conformação cis, sendo notada a predominância de produtos 18:1 trans e produtos saturados. Isto pode ser explicado principalmente pela maior estabilidade do éster saturado e monoinsaturado de conformação trans comparado com seu isômero cis. ${ }^{22}$ Uma outra possível explicação é pelo alto ponto de fusão destes ésteres (18:1 trans: $43,7^{\circ} \mathrm{C}$ e 18:0: $69,3{ }^{\circ} \mathrm{C}$ ) e a maior viscosidade e maior dificuldade destes de interagirem com a superfície do catalisador em função da geometria linear.

As reações para o estudo da influência do tempo na taxa de hidrogenação foram feitas mantendo as condições reacionais fixas $\left(12,5 \mathrm{~atm}, 60^{\circ} \mathrm{C}\right.$ e $0,1 \mathrm{~g}$ de catalisador para $\mathrm{Pt}$ e $\mathrm{Pt} / \mathrm{Pd}$ ). Os tempos para a retirada de alíquotas foram $2 \mathrm{~h}, 4 \mathrm{~h}, 6 \mathrm{~h}$ e $14 \mathrm{~h}$. A massa de catalisador maior foi escolhida a fim de evitar que pequenas perdas na lavagem sejam significativas frente à massa empregada. Durante o estudo não foi notada perda de catalisador maior que $0,2 \mathrm{mg}$, que está dentro da incerteza da balança.

Os resultados cromatográficos podem ser verificados na Figura 10 a seguir. 


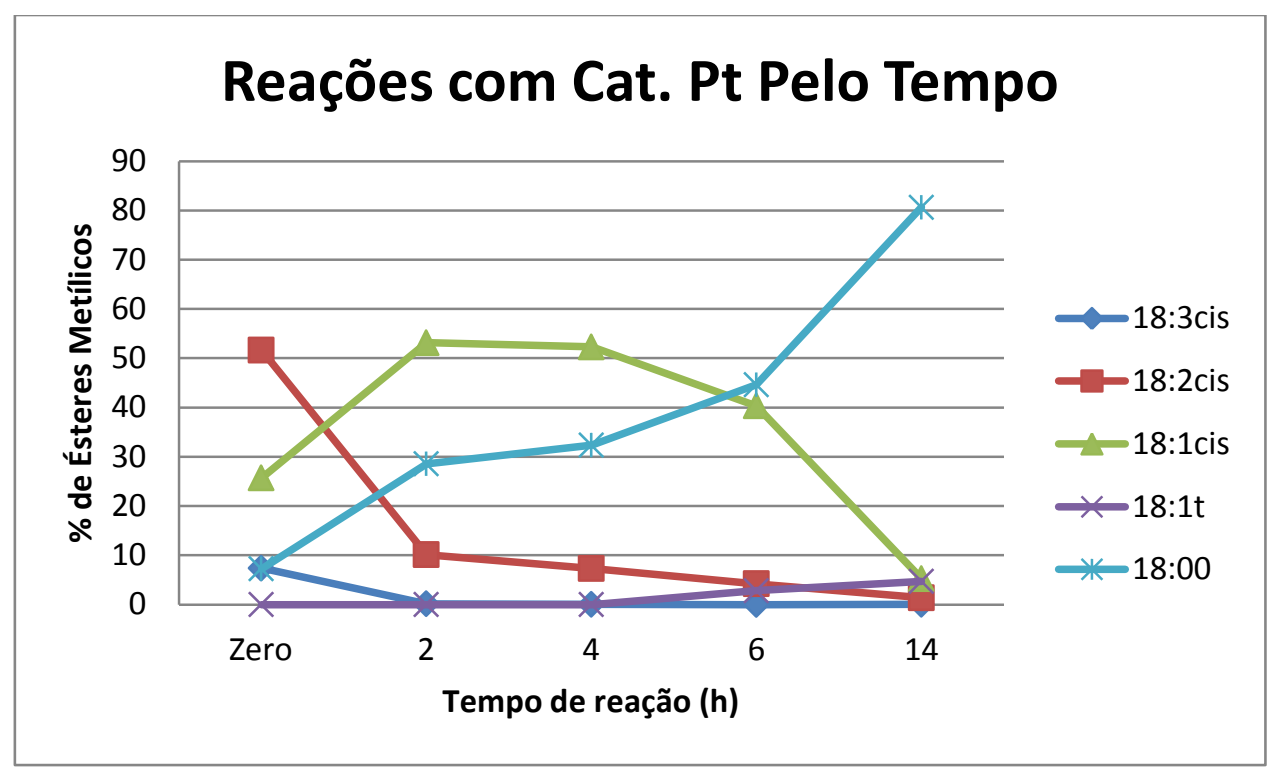

Figura 10: Porcentagens dos ésteres metílicos de soja hidrogenados com diferentes tempos reacionais para o catalisador de Pt.

A hidrogenação foi iniciada logo nas primeiras $2 \mathrm{~h}$, e a maior conversão de ésteres insaturados em produtos hidrogenados quando comparada com a reação 2 é explicada pela maior massa de catalisador empregada, que, como foi observado no estudo da melhor massa de catalisador para as reações de hidrogenação, é um fator importante e limitante na reação.

Foi possível também notar que o catalisador, a partir de $4 \mathrm{~h}$ gerou uma quantidade decrescente de produtos 18:1 cis, mostrando que a hidrogenação dos ésteres poli-insaturados a 18:1 cis diminuiu e a hidrogenação do 18:1 cis ficou mais expressiva. A presença de produtos 18:1 trans apenas a partir de $6 \mathrm{~h}$ de reação mostrou que há seletividade do catalisador de Pt para formação de isômeros cis e esta formação de isômeros trans pode ser explicada pela diminuição da quantidade de $\mathrm{H}_{2}$ disponível no meio, proporcionando a isomerização das moléculas insaturadas.

Após $14 \mathrm{~h}$ de reação praticamente todas as insaturações foram hidrogenadas, restando apenas uma pequena quantidade de produtos insaturados, que devido à alta viscosidade dos ésteres no meio, mesmo a $60{ }^{\circ} \mathrm{C}$, dificulta bastante a permeação de hidrogênio e o transporte de moléculas na superfície do catalisador.

Os mesmos testes foram repetidos para o catalisador de $\mathrm{Pt} / \mathrm{Pd}$ para avaliar a diferença na evolução dos produtos trans e comparar a seletividade destes catalisadores. 
Os resultados cromatográficos podem ser conferidos na Figura 11 a seguir.

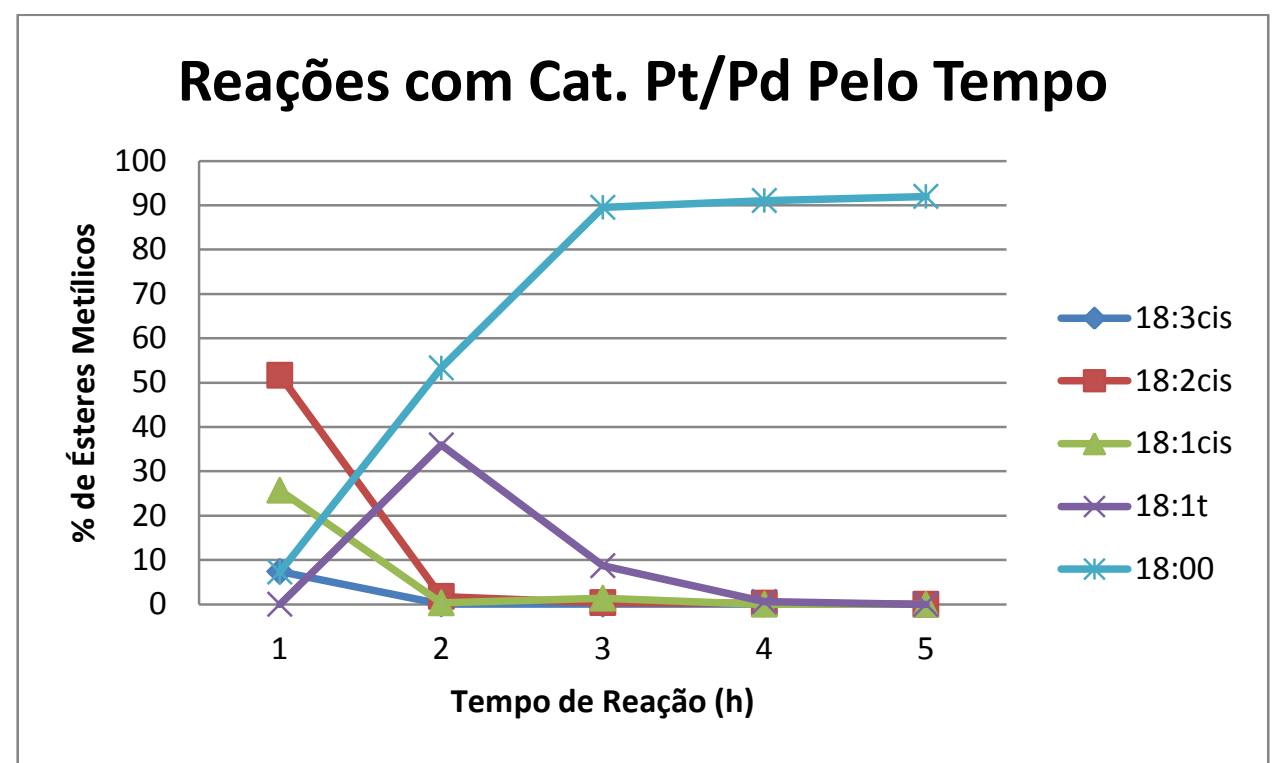

Figura 11: Porcentagens dos ésteres metílicos de soja hidrogenados com diferentes tempos reacionais para o catalisador de $\mathrm{Pt} / \mathrm{Pd}$.

Foi verificada a maior atividade deste catalisador de $\mathrm{Pt} / \mathrm{Pd}$ quando comparado com o catalisador de Pt. É possível notar também que nas primeiras $2 \mathrm{~h}$ quase todos os ésteres poli-insaturados foram hidrogenados a 18:1 e 18:0, sendo que a partir de $4 \mathrm{~h}$ praticamente não há mais insaturações na mistura.

Há menor seletividade para a formação de produtos cis neste catalisador, reforçando a necessidade de emprego de solventes ou algum outro meio que auxilie na seletividade dos produtos para evitar problemas antes discutidos como a temperatura de congelamento.

É possível concluir, para os dois catalisadores, que o tempo de $2 \mathrm{~h}$ é ideal para a formação de um biodiesel hidrogenado, porém líquido, com maior porcentagem de oleato de metila. 


\subsubsection{Estudo do reciclo dos catalisadores para a reação de hidrogenação de biodiesel sob condições reacionais fixas}

O estudo do reciclo dos catalisadores tem como objetivo verificar a atividade dos catalisadores durante o seu reuso, para verificar a resistência destes catalisadores e também a perda de atividade seja por impregnação de subprodutos ou mesmo por sinterização. Este estudo foi feito para verificar quantas reações estes catalisadores mantêm suas atividades sem a necessidade de recuperação por redução em atmosfera de hidrogênio e alta temperatura.

As condições reacionais foram: $60{ }^{\circ} \mathrm{C}, 12,5 \mathrm{~atm}, 2 \mathrm{~h}$, agitação constante e $0,1 \mathrm{~g}$ de catalisador tanto para o de Pt quanto para o de $\mathrm{Pt} / \mathrm{Pd}$.

É notável no gráfico A da Figura 12 que houve grande variação nos produtos no primeiro uso do catalisador, porém esta variação foi diminuída quando o catalisador foi reciclado pela primeira vez, principalmente quanto à formação de ésteres metílicos 18:1 cis. Até o segundo reciclo a hidrogenação de cadeias com três insaturações foi praticamente total, a partir do terceiro reciclo o catalisador foi lentamente perdendo esta capacidade. Outra observação importante foi a formação de compostos 18:1 trans a partir do quarto reciclo do catalisador, mostrando que a seletividade deste é perdida quando há vários reciclos deste sem uma regeneração do catalisador por redução. No quinto reciclo o catalisador perdeu praticamente toda a sua atividade para a hidrogenação nestas condições e facilitou a isomerização de cadeias monoinsaturadas, mostrando que sem a regeneração do catalisador a cada 2 reciclos a atividade passa a ser muito baixa para a hidrogenação de biodiesel de soja sob as condições destas reações.

No gráfico $\mathrm{B}$ da Figura 12 é possível notar que o catalisador de $\mathrm{Pt} / \mathrm{Pd}$ manteve melhor a atividade em função dos reciclos que o catalisador de Pt. Isto pode ser explicado em função de este ter uma atividade consideravelmente melhor para a reação de hidrogenação mesmo quando utilizado em mesmas proporções molares. É possível notar também que há uma alta formação de isômeros trans, principalmente monoinsaturados e até $\circ 3^{0}$ reciclo esta formação é crescente. Após $\circ 3^{0}$ reciclo 0 catalisador perde a atividade rapidamente a cada reação e no $5^{0}$ reciclo há pouca reação de hidrogenação. É possível afirmar que este catalisador mantêm uma atividade 
considerável até $\circ 3^{0}$ reciclo, mantendo baixas porcentagens de compostos poliinsaturados e mantendo altos índices de compostos monoinsaturados e saturados.

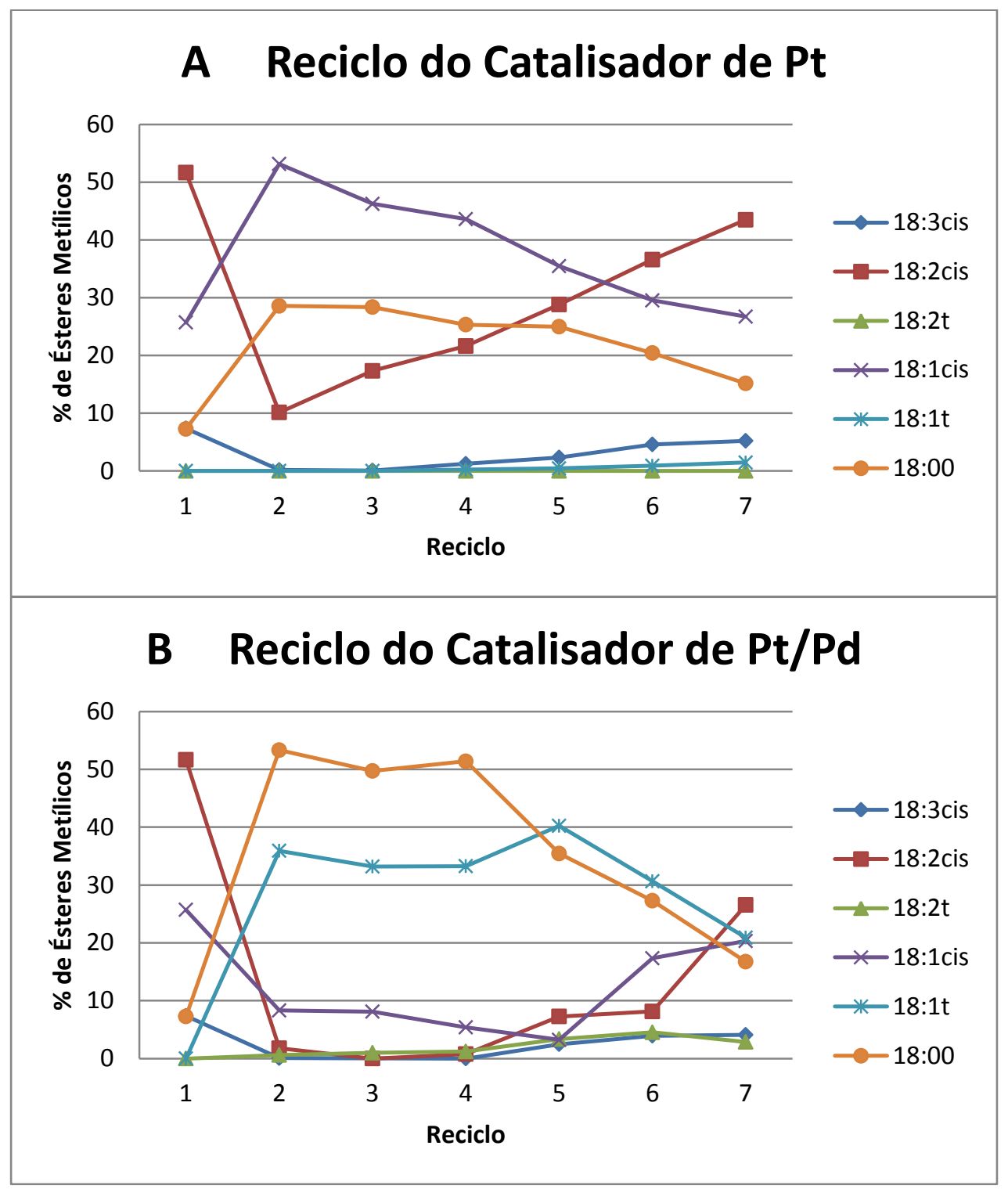

Figura 12: Porcentagens de ésteres metílicos em função do reciclo do catalisador. A: reações com catalisador de Pt, B: reações com catalisador de Pt/Pd.

A perda de atividade dos catalisadores pode ser explicada por sinterização destes, causando também o aumento das partículas e a diminuição das áreas superficiais ou pelo acúmulo de subprodutos na superfície dos catalisadores.

Uma alternativa para a melhora da atividade catalítica é a utilização de processos de lavagens dos catalisadores em banhos ultrassônicos e a regeneração destes. 


\subsubsection{Estudo da influência dos líquidos iônicos nas reações de hidrogenação de biodiesel de soja}

Os líquidos iônicos influenciam diretamente na reação de hidrogenação, agindo na solubilidade dos reagentes e produtos e também facilitando a dispersão dos catalisadores e podendo ate mesmo interagir com os catalisadores.

Para o estudo da influência dos líquidos iônicos nestas reações foi proposta uma aplicação deste em massa suficiente para a total dispersão do catalisador em meio iônico para que então o biodiesel fosse adicionado a fim de não haver dispersão do catalisador no biodiesel diretamente.

As reações foram feitas com $1 \mathrm{~g}$ de líquido iônico BMI.BF 4 e BMI.NTf 2,75 atm, temperatura de $60{ }^{\circ} \mathrm{C}$, e massa de catalisador de $0,025 \mathrm{~g}$ para o catalisador de $\mathrm{Pt} \mathrm{e}$ $0,034 \mathrm{~g}$ para o catalisador de Pt/Pd. As reações foram feitas e alíquotas de 0,019 g de biodiesel (produto) eram retiradas para análise de CLAE em determinados momentos para o acompanhamento cinético da hidrogenação.

A Figura 13 mostra os resultados para os diversos tempos reacionais da

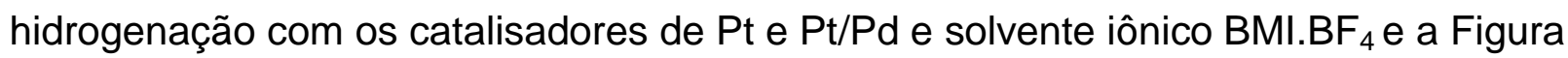
15 mostra os resultados dos diversos tempos reacionais com o líquido iônico BMI.NTf 2 . 


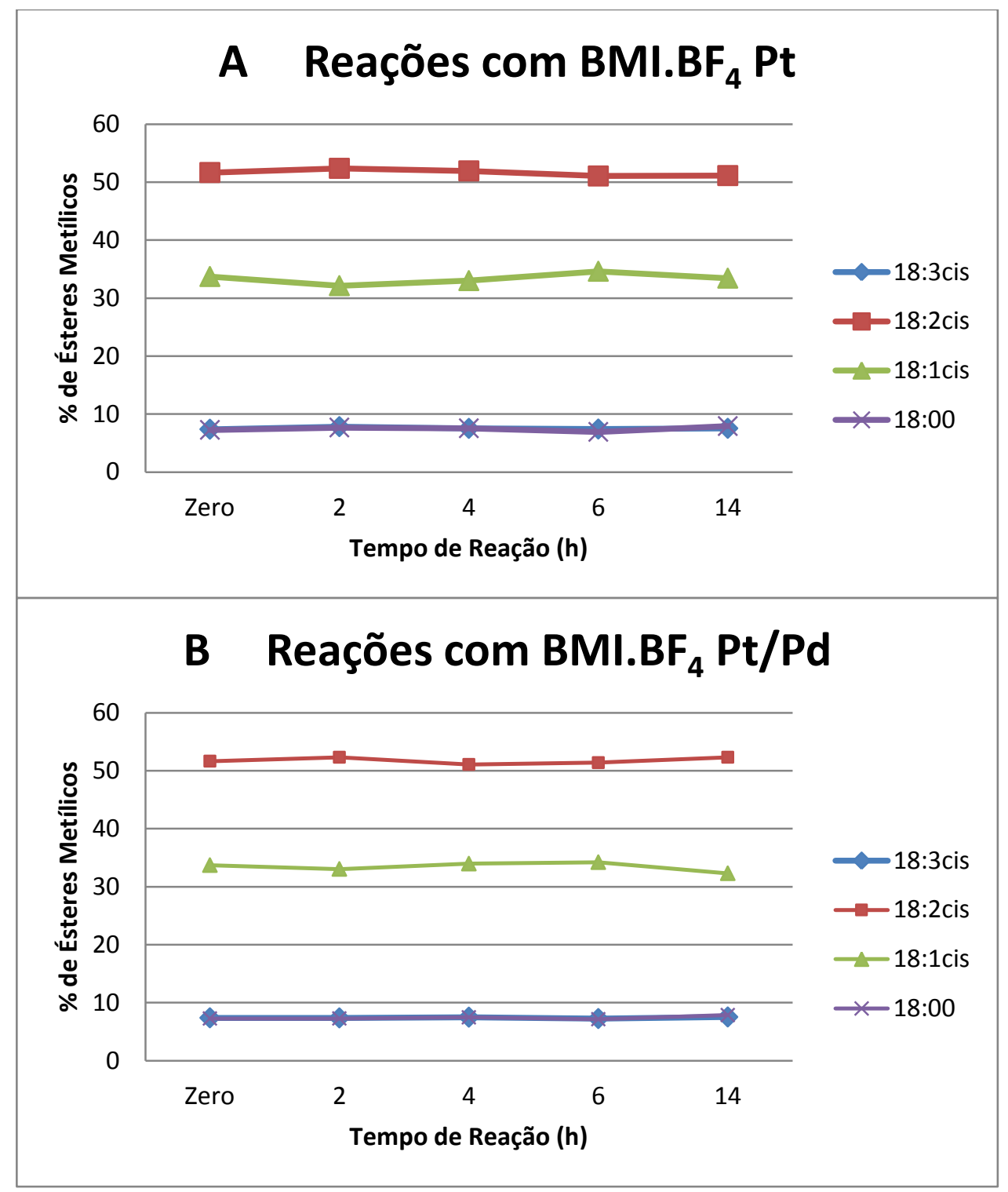

Figura 13: Porcentagens de ésteres metílicos em função do tempo de reação de hidrogenação com solvente iônico $\mathrm{BMI}_{\mathrm{BF}}$. A: reações com 0 catalisador $\mathrm{Fe}_{3} \mathrm{O}_{4} @ \mathrm{mSiO}{ }_{2} @ \mathrm{Pt}$ e B: reações com o catalisador $\mathrm{Fe}_{3} \mathrm{O}_{4} @ \mathrm{mSiO} \mathrm{O}_{2} @ \mathrm{Pt} / \mathrm{Pd}$.

Foi verificado que não há reação significativa de hidrogenação dos ésteres metílicos com ambos catalisadores, mesmo depois de $14 \mathrm{~h}$ de reação, as variações verificadas nos gráficos são em função dos limites e da exatidão e precisão do método (anexos 7.1 e 7.2) e também em função de erros na amostragem (pipeta e balança) ou mesmo do equipamento de detecção de absorção de luz ultravioleta.

Uma possível explicação para esta não hidrogenação do biodiesel é a interação entre o líquido iônico e o suporte do catalisador, a sílica mesoporosa, onde pode haver 
interações de Van Der Waals que são mais expressivas em função da grande área superficial da sílica mesoporosa. Esta interação entre suporte e solvente impede ou dificulta muito o acesso ou permeação do biodiesel nos mesoporos, impedindo o contato do biodiesel com os sítios catalíticos.

Outra possível explicação para a ausência de hidrogenação pode estar

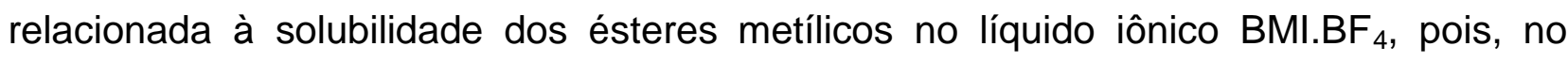
preparo da reação, os catalisadores são primeiramente dispersados no solvente iônico para em seguida ser adicionado o biodiesel. Sendo assim, o biodiesel não está em contato direto com o catalisador, para haver o contato os ésteres necessitam entrar em solução no solvente iônico para então hidrogenarem na superfície do catalisador. Se não há boa solubilidade dos ésteres metílicos do óleo de soja no líquido iônico BMI.BF 4 não há muito contato destas moléculas com os catalisadores e a hidrogenação será dificultada.

Outra possibilidade considerada foi a degradação dos íons de $\mathrm{BF}_{4}{ }_{4}$ gerando íons $\mathrm{F}^{-}$no meio ou mesmo a contaminação do líquido iônico com $\mathrm{Cl}^{-}$, estes ânions podem gerar cloretos e fluoretos com a Platina. Para tanto foi testada a presença de fluoretos resultantes da decomposição do ânion $\mathrm{BF}_{4}{ }^{-}$por método de precipitação com a adição de uma solução $0,3 \mathrm{M}$ de $\mathrm{AgNO}_{3}$ diretamente em uma pequena fração do líquido iônico, porém não foi notada a formação de qualquer precipitado.

Para avaliar melhor o que poderia estar influenciando a inatividade dos catalisadores de Pt e Pt/Pd foi feita uma Microscopia Eletrônica de Varredura após uma série de lavagens ( a fim de remover da superfície dos catalisadores qualquer impureza de solvente iônico e ésteres metílicos assim como outros subprodutos da reação) com os solventes ciclohexano, diclorometano, acetonitrila e acetona, respectivamente.

As imagens de microscopia eletrônica são apresentadas na Figura 14 a seguir. 


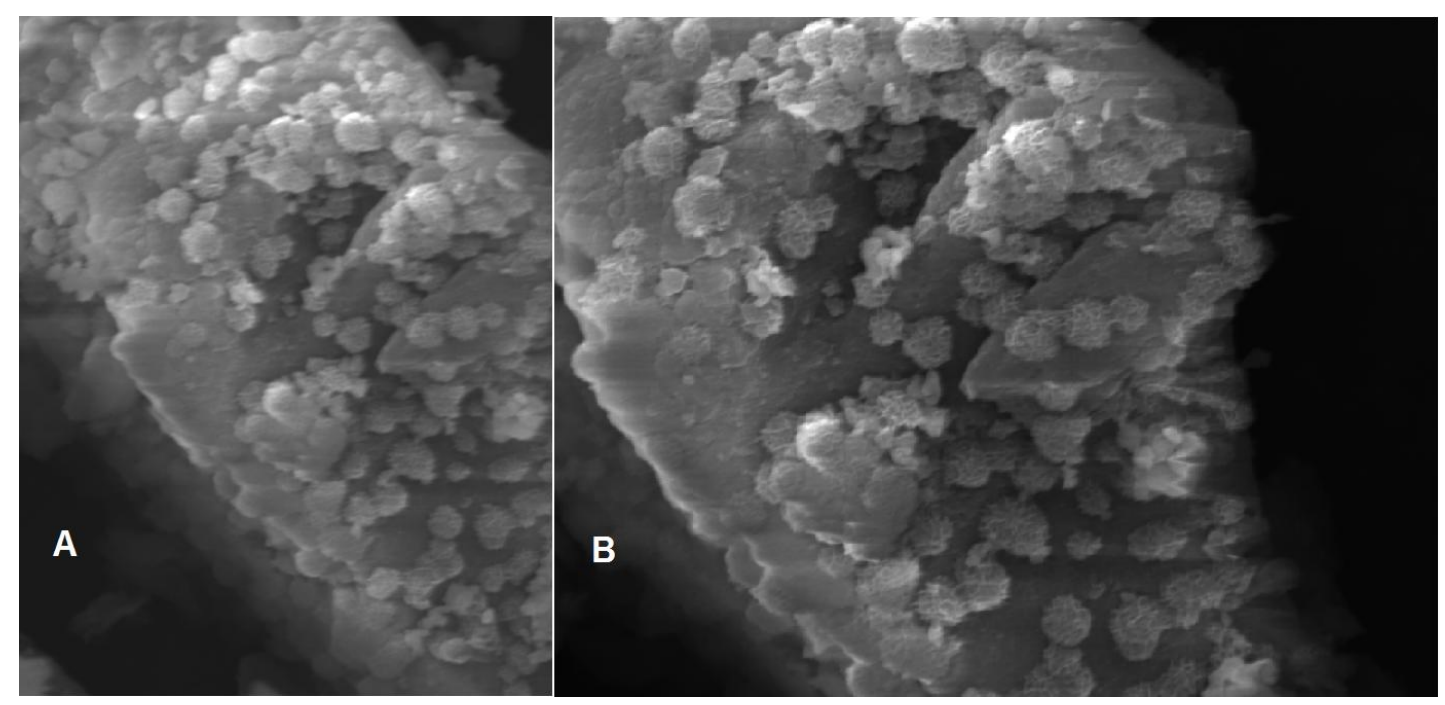

Figura 14: Microscopia Eletrônica de Varredura do catalisador $\mathrm{Fe}_{3} \mathrm{O}_{4} @ \mathrm{mSiO}_{2} @ \mathrm{Pt}$ após

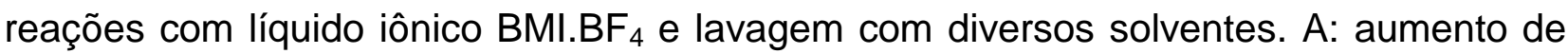
2.300 x e B: aumento de $4.500 \mathrm{x}$.

Verificou-se um aglomerado de nanopartículas com forma indefinida e algumas formações bem definidas e esféricas que remetem a gotas, que foram associadas a líquido iônico na superfície do aglomerado de nanopartículas. Esta interpretação foi reforçada pela persistência da umidade na amostra mesmo após secagem, pois o

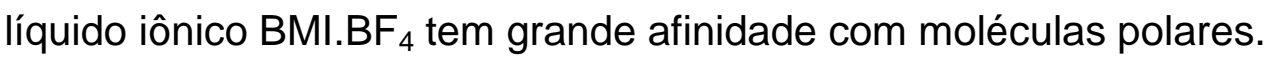

Esta é uma possível explicação para a inatividade dos catalisadores para

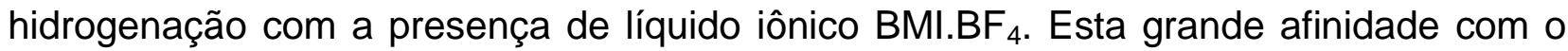
catalisador, faz com que o líquido iônico em estudo interaja nos mesoporos do suporte de sílica e bloqueie o catalisador em sua superfície, preenchendo-o e impedindo a permeação de ésteres metílicos principalmente.

Ainda são necessários estudos mais aprofundados e específicos para comprovar esta explicação, com equipamentos com maior resolução e maior aumento da imagem para poder confirmar a entrada do solvente iônico em questão nos mesoporos do suporte.

Os testes com o líquido iônico BMI.NTf ${ }_{2}$ foram realizados com as mesmas condições reacionais e os mesmos tempos de amostragens. Os resultados cromatográficos podem ser verificados na Figura 15 a seguir. 


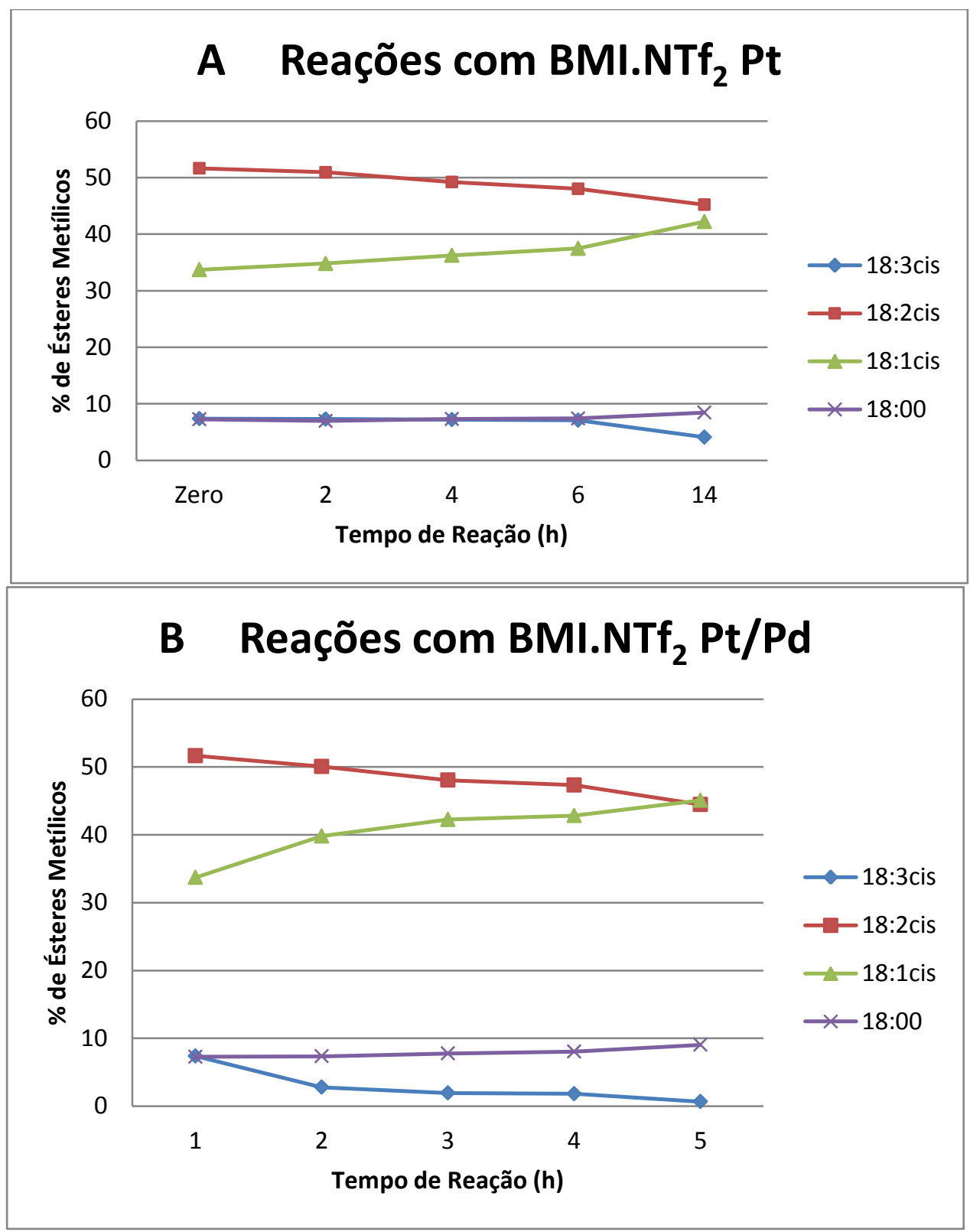

Figura 15: Porcentagens de ésteres metílicos em função do tempo de reação de hidrogenação com solvente iônico BMI.NTf $f_{2}$. A: reações com 0 catalisador $\mathrm{Fe}_{3} \mathrm{O}_{4} @ \mathrm{mSiO}{ }_{2} @ P t$ e B: reações com o catalisador $\mathrm{Fe}_{3} \mathrm{O}_{4} @ \mathrm{mSiO}{ }_{2} @ \mathrm{Pt} / \mathrm{Pd}$.

Com o solvente iônico BMI.NTf $f_{2}$ houve hidrogenação para ambos catalisadores empregados, porém a cinética das reações foi muito lenta quando comparada com as reações sem solvente. É possível também notar que houve um aumento significativo na formação de cadeias 18:1 cis, o que pode ser explicado pela maior solubilidade de 18:3 cis e 18:2 cis no solvente, então quando estes reagentes são hidrogenados a 18:1 cis, 
produto de menor solubilidade, os produtos saem da solução, diminuindo o contato com o catalisador.

Em comparação com a hidrogenação sem solvente iônico, a hidrogenação com BMI.NTf 2 mostrou grande melhora na seletividade na formação de cadeias 18:1 cis, mesmo quando comparada com as reações com o catalisador de Pt. Isto mostra que o emprego de líquido iônico BMI.NTf ${ }_{2}$ aumenta consideravelmente a seletividade, porém diminui consideravelmente a velocidade da reação, principalmente em função de os ésteres metílicos poli-insaturados precisarem permear o solvente para então entrarem em contato com o catalisador, o mesmo fenômeno ocorre para o gás $\mathrm{H}_{2}$.

\subsection{Análises Físico-Químicas dos Produtos Hidrogenados}

Os produtos de hidrogenação foram analisados em suas propriedades de densidade, viscosidade, estabilidade oxidativa e calorimetria exploratória diferencial.

A densidade e a viscosidade tem como objetivo verificar se a reação de hidrogenação modifica estas propriedades no combustível e se estas propriedades estão dentro das normas estabelecidas pela ANP. ${ }^{15}$

A estabilidade oxidativa tem como objetivo verificar se houve aumento ou diminuição da estabilidade à oxidação do combustível após as reações de hidrogenação a fim de estudar a melhora deste combustível no quesito de durabilidade.

A calorimetria exploratória diferencial tem como objetivo estudar as principalmente as propriedades a frio do biodiesel e dos produtos de hidrogenação deste, a fim de verificar a interferência da hidrogenação nas propriedades a frio, e se após a hidrogenação os produtos apresentam grande variação no ponto de fusão.

Todas as medidas de densidade e viscosidade foram realizadas em triplicata, enquanto a estabilidade oxidativa e a calorimetria exploratória diferencial foram feitas em apenas uma replicata. Os resultados foram comparados com a norma de especificação do biodiesel descrita pela ANP a fim de comparar a qualidade do biodiesel sintetizado e dos produtos hidrogenados neste trabalho. Dois produtos de hidrogenação (amostra 2 e amostra 6) foram escolhidos para verificar estas propriedades físico-químicas em função de estes serem líquidos à temperatura ambiente $\left(27,5{ }^{\circ} \mathrm{C}\right)$ e apresentarem alta quantidade de ésteres metílicos monoinsaturados (18:1 cis ou trans). ${ }^{15}$ 
Os valores de densidade e viscosidade do biodiesel e das amostras 2 e 6 podem ser verificados na Tabela 15 a seguir.

Tabela 15: Densidade e viscosidade do biodiesel e dos produtos de hidrogenação,e valores de referência estabelecidos pela ANP*.

\begin{tabular}{|c|c|c|}
\hline Amostra & $\begin{array}{l}\text { Densidade } \\
\mathrm{kg} / \mathrm{m}^{3}\end{array}$ & $\begin{array}{c}\text { Viscosidade } \\
\mathrm{mm}^{2} / \mathrm{s}\end{array}$ \\
\hline Biodiesel & 863 & 3.8 \\
\hline 2 & 860 & 4.0 \\
\hline 6 & 852 & 4.9 \\
\hline
\end{tabular}

\begin{tabular}{l}
$\begin{array}{c}\text { Especificacãa } \\
\text { da ANP }\end{array} \quad 850-900 \quad 3.0-6.0$ \\
\hline
\end{tabular}

* Resolução ANP № 45, de 25/08/2014 - DOU 26/08/2014; Densidade (massa específica) a $20^{\circ} \mathrm{C}$; Viscosidade cinemática a $40^{\circ} \mathrm{C} .{ }^{15}$

Primeiramente, o biodiesel e as amostras 2 e 6 estão dentro dos limites de viscosidade e densidade permitidos pela ANP, porém a amostra 6 fica bem próxima ao limite mínimo de densidade. ${ }^{15}$

É possível notar que quanto maior a hidrogenação do biodiesel e maior a porcentagem de cadeias lineares na composição do biodiesel maior é a viscosidade e menor é a densidade desta mistura, isto pode ser explicado pelo maior grau de "empacotamento" das cadeias, o que aumenta sua viscosidade enquanto que a densidade é diminuída. Isso ocorre devido aos acréscimos das cadeias menos insaturadas, o que diminui a densidade na proporção em que são aumentadas as cadeias mono insaturadas e saturadas. As densidades individuais dos ésteres metílicos podem ser conferidas na Tabela 16 apresentada a seguir.

Tabela 16: Valores de Densidade de ésteres metílicos puros. ${ }^{50,51,52,53}$

\begin{tabular}{ccc}
\hline $\begin{array}{c}\text { Éster } \\
\text { Metílico }\end{array}$ & $\begin{array}{c}\text { Densidade } \\
\left(\mathbf{k g} / \mathbf{m}^{3}\right)\end{array}$ & $\begin{array}{c}\text { Temperatura } \\
\left({ }^{\circ} \mathbf{C}\right)\end{array}$ \\
\hline $18: 0$ & 850 & 40 \\
$18: 1$ cis & 874 & 20 \\
$18: 2$ & 889 & 25 \\
$18: 3$ & 895 & 25 \\
\hline
\end{tabular}


Após estas análises, foram realizadas as análises de estabilidade à oxidação do biodiesel e das amostras 2 e 6 . A metodologia utilizada foi a mesma adotada pela ANP (Resolução ANP № 45, de 25/08/2014 - DOU 26/08/2014): Estabilidade à oxidação a $110 \stackrel{\circ}{\circ} .^{15}$

Os resultados destes testes podem ser verificados nos gráficos a seguir.

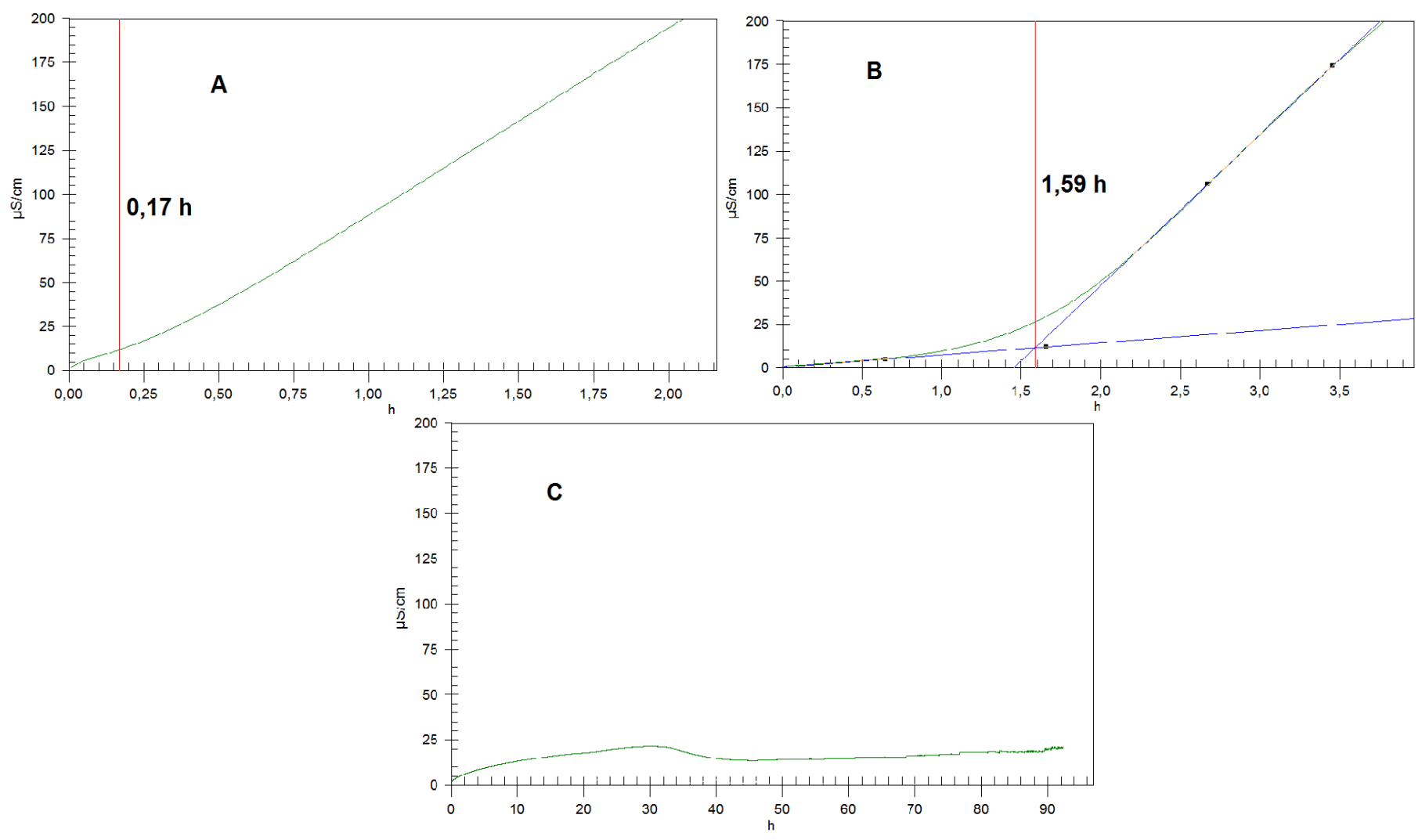

Figura 16: Gráficos de estabilidade oxidativa do A: Biodiesel, B: amostra 2 e C: amostra 6.

A partir da resolução ANP № 45, de 25/08/2014 - DOU 26/08/2014 que determina como tempo mínimo de estabilidade à oxidação $8 \mathrm{~h}$, desde $1^{\circ}$ de Novembro de 2014, é possível verificar que o gráfico de estabilidade oxidativa do biodiesel não hidrogenado $(A)$ mostra que a estabilidade à oxidação deste está bem abaixo do mínimo permitido, assim como o produto de hidrogenação do gráfico $\mathrm{B}$, amostra 2. Vale pontuar que não há nenhum aditivo antioxidante nas amostras deste trabalho e isto justifica a estabilidade estar abaixo do permitido pela ANP. ${ }^{15}$

A amostra de biodiesel hidrogenado líquida que mostrou melhor estabilidade à oxidação foi a amostra 6 , que teve tempo de indução superior a $30 \mathrm{~h}$. Pois a partir de 
certo tempo de análise, a referência (condutividade da água) começa a ser adulterada devido a evaporação.

Porém, não só a estabilidade à oxidação, sua composição e suas propriedades de viscosidade e densidade são importantes para que um combustível seja aplicável em motores com eficiência, pois se este for sólido à certas temperaturas ele não será útil, principalmente em determinadas regiões frias, podendo então causar entupimentos e mau funcionamento dos motores. Para regulamentar isto a ANP determinou em resolução de № 45 de 25/08/2014 - DOU 26/08/2014 que, para os estados de GO, DF, MT, ES e RJ, as temperaturas de entupimento a frio sejam de $14^{\circ} \mathrm{C}$ entre Janeiro e Abril e Outubro e Dezembro e $10^{\circ} \mathrm{C}$ entre Maio e Setembro. Portanto é necessário garantir que o ponto de entupimento a frio do biodiesel melhorado por meio da hidrogenação esteja sempre abaixo dos $10^{\circ} \mathrm{C}$ para garantir seu uso em qualquer época do ano. ${ }^{15}$

O ponto de fusão foi avaliado por calorimetria diferencial exploratória, que mostra o perfil de mudança de fases (ponto de fusão) dos combustíveis em função da temperatura. Os resultados podem ser conferidos no gráfico a seguir.

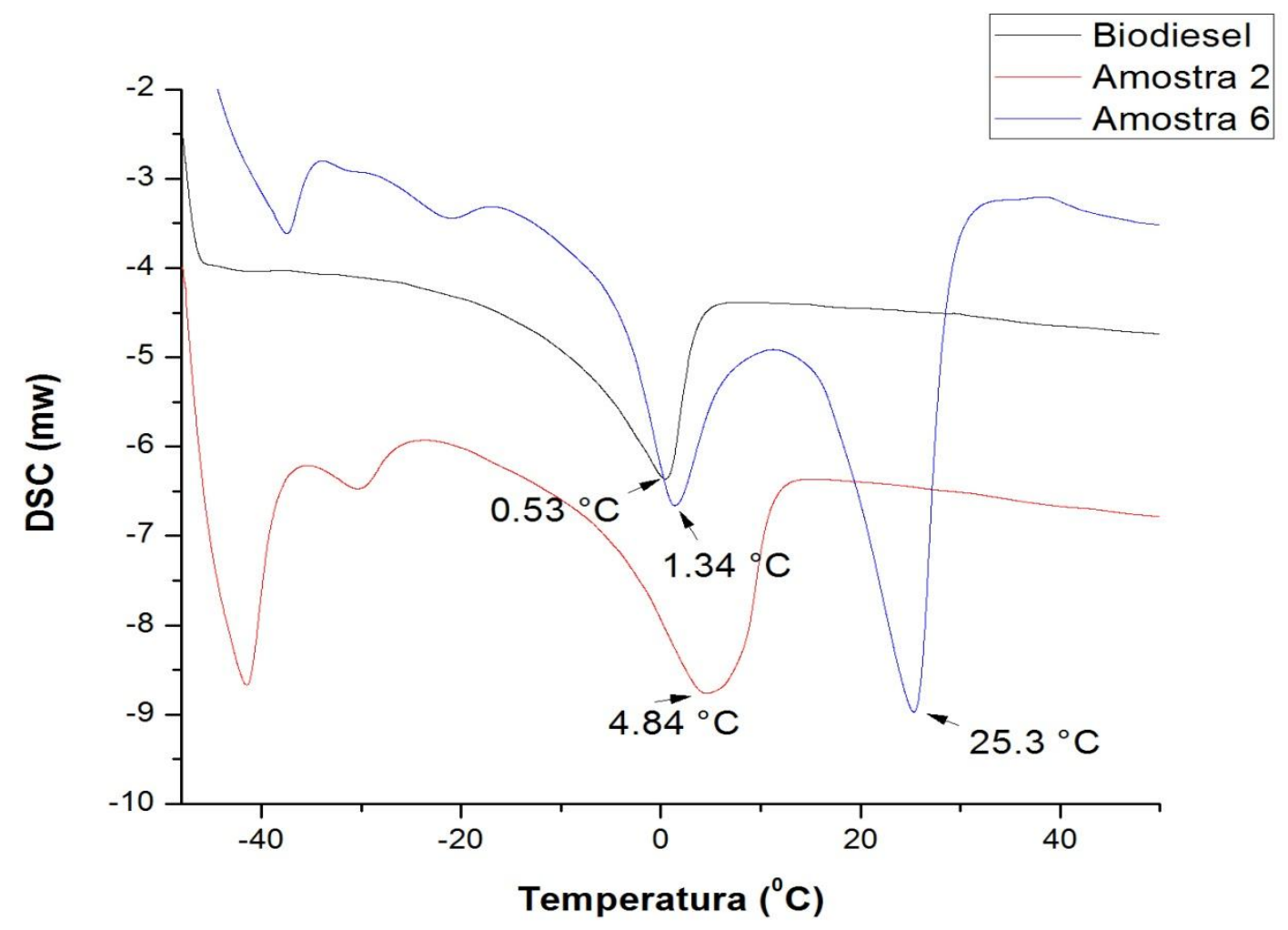

Figura 17: Gráfico de calorimetria exploratória diferencial do biodiesel, amostra 2 e amostra 6 de $-50^{\circ} \mathrm{C}$ a $50^{\circ} \mathrm{C}$. 
É possível verificar pelos gráficos que o biodiesel possui um ponto de congelamento muito próximo a $0{ }^{\circ} \mathrm{C}$, enquanto os produtos hidrogenados possuem pontos de congelamento superiores.

A amostra 2 teve uma mudança de um pouco mais de $4{ }^{\circ} \mathrm{C}$ no ponto de fusão em relação ao biodiesel, mostrando que a hidrogenação seletiva (para 18:1 cis) empregando catalisador de $\mathrm{Fe}_{3} \mathrm{O}_{4} @ \mathrm{mSiO}_{2} @ \mathrm{Pt}$ mostrou bons resultados quanto ao quesito de propriedades a frio.

A amostra 6 teve dois pontos de fusão, que foram atrelados às diferentes composições de ésteres na mistura deste biodiesel hidrogenado. Estes pontos se mostraram mais expressivos e tiveram temperaturas de fusão separadas em função do alto teor de ésteres saturados e monoinsaturados lineares (trans) e um pequeno teor (menos de $20 \%$ ) de ésteres insaturados cis. O ponto de fusão mais alto foi de $25,3{ }^{\circ} \mathrm{C}$, muito alto e fora das especificações da ANP, e podendo causar entupimento de motores ou mesmo danos às peças destes, portanto este biodiesel não é aplicável puro para a mistura com o diesel de petróleo. ${ }^{15}$ 


\section{CONCLUSÕES E PERSPECTIVAS}




\section{Conclusões e perspectivas}

A hidrogenação de biodiesel utilizando catalisadores de $\mathrm{Pt}$ e $\mathrm{Pt} / \mathrm{Pd}$ em suporte magnético do tipo core-shell é efetiva e altamente seletiva no caso do catalisador de Platina pura. A separação do catalisador ao final da reação foi facilmente realizada por meio do emprego de um imã de neodímio e após a lavagem do catalisador com solventes não foi notada perda mássica do catalisador, o que mostrou resultados promissores.

A comparação dos dois catalisadores empregados neste estudo mostrou que o catalisador de Pt é mais seletivo, porém com menor atividade quando comparado com o catalisador bimetálico de Pt/Pd.

Para os estudos da reação de hidrogenação com o emprego de solventes iônicos foi notada a dificuldade desta reação ocorrer, possivelmente por interações entre a sílica

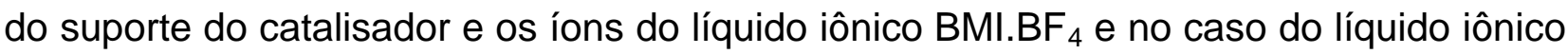
BMI.NTf $f_{2}$ a velocidade da reação foi diminuída, também possivelmente em função de interações entre o líquido iônico e o catalisador porém são necessários estudos mais específicos para melhor explicação dos fenômenos que impossibilitam a viabilidade da hidrogenação com solventes iônicos nas condições em estudo. Para melhorar estas reações, diferentes condições reacionais e diferentes solventes iônicos devem ser mais profundamente estudados.

Foi possível notar que o aumento da massa de catalisador, da pressão, da temperatura e do tempo reacional proporcionaram aumentos correspondentes na formação de produtos hidrogenados para ambos catalisadores deste trabalho, porém foram notadas mudanças na seletividade quando foram modificadas a temperatura e a pressão de $\mathrm{H}_{2}$ no meio reacional. Também foram alcançadas boas taxas de hidrogenação com baixas concentrações de catalisadores, o que mostra um ponto positivo frente ao custo destes.

Quando estudado o reciclo dos catalisadores verificou-se que o catalisador de $\mathrm{Pt}$, após 2 reciclos (3 reações) começa a ter perda significativa de atividade e seletividade. Para o catalisador de $\mathrm{Pt} / \mathrm{Pd}$ foram obtidas 4 reações ( 3 reciclos) com ótima atividade. Estes resultados mostram que para cada grama de $\mathrm{Fe}_{3} \mathrm{O}_{4} @ m \mathrm{mSiO}_{2} @ \mathrm{Pt}$ é possível obter $1200 \mathrm{~g}$ de biodiesel parcialmente hidrogenado e para cada grama de 
$\mathrm{Fe}_{3} \mathrm{O}_{4} @ \mathrm{mSiO} \mathrm{S}_{2} @ \mathrm{Pt} / \mathrm{Pd}$ é possível obter $1176 \mathrm{~g}$ de biodiesel parcialmente hidrogenado. Uma possibilidade para o melhoramento destes resultados é a regeneração por redução destes catalisadores.

As reações que proporcionaram melhores condições reacionais foram: $0,025 \mathrm{~g}$ de catalisador, $10 \mathrm{~g}$ de biodiesel, $12,5 \mathrm{~atm}$ de $\mathrm{H}_{2}, 60{ }^{\circ} \mathrm{C}$ e $2 \mathrm{~h}$ de reação, sob constante agitação (para o catalisador de Pt) e 0,034 $\mathrm{g}$ de catalisador, $10 \mathrm{~g}$ de biodiesel, $12,5 \mathrm{~atm}$ de $\mathrm{H}_{2}, 60{ }^{\circ} \mathrm{C}$ e $2 \mathrm{~h}$ de reação, sob constante agitação (para o catalisador de $\mathrm{Pt} / \mathrm{Pd}$ ). Nestas condições os produtos obtidos são líquidos à temperatura ambiente $\left(27,5^{\circ} \mathrm{C}\right) \mathrm{e}$ apresentam altos teores de ésteres monoinsaturados.

As análises físico-químicas das amostras 2 e 6 mostraram que apesar de nenhum dos dois e muito menos o biodiesel estarem completamente dentro das especificações da ANP (principalmente em função da ausência de aditivos antioxidantes) estes produtos podem ser aplicados em blendas com o biodiesel aditivado de antioxidantes a fim de diminuir a necessidade desses ou mesmo podem ser misturados (a amostra 2 com a amostra 6) para se obter o melhor de cada uma seja na alta estabilidade oxidativa da amostra 6 ou no baixo ponto de fusão da amostra 2 .

As perspectivas são que este trabalho gere interesse no estudo da influência dos líquidos iônicos quando empregados como solventes de catalisadores com suportes mesoporosos e as interações entre os diferentes suportes e os diferentes solventes iônicos.

Para os catalisadores as perspectivas são: o desenvolvimento de catalisadores do tipo core-shell magnéticos com diferentes superfícies (shell) como carbono ativado, alumina, alumino silicatos porosos e diferentes metais catalisadores como o Bismuto, Rutênio, Tungstênio e outros metais com conhecida atividade para reações de hidrogenação. Também é necessário o estudo da influência da dimensão e estrutura dos poros no suporte para a distribuição do catalisador e formação dos produtos. 
REFERÊNCIAS 


\section{REFERÊNCIAS}

1. SHAY, E.griffin. Diesel fuel from vegetable oils: Status and opportunities. Biomass And Bioenergy, [s.I.], v. 4, n. 4, p.227-242, jan. 1993. Elsevier BV.

2. MA, Fangrui; A HANNA, Milford. Biodiesel production: a review Journal Series $n$ 12109. Bioresource Technology, [s.I.], v. 70, n. 1, p.1-15, out. 1999. Elsevier BV.

3. Chemical \& Metallurgical Engineering, May 1943, vol. 50, p. 225.

4. O Primeiro Choque do Petróleo em 1973. Folha on line. Disponível em: <http://www1.folha.uol.com.br/folha/dinheiro/petroleo_choque1.shtml>. Acesso em 04 de Maio de 2015.

5. O Segundo Choque do Petróleo em 1979. Folha on line. Disponível em: <http://www1.folha.uol.com.br/folha/dinheiro/petroleo_choque2.shtml>. Acesso em 04 de Maio de 2015.

6. A Guerra do Golfo. Folha on line. Disponível em: <http://www1.folha.uol.com.br/folha/dinheiro/petroleo_golfo.shtml>. Acesso em 04 de Maio de 2015.

7. SUAREZ, P. A. Z. et al. Transformação de triacilgricerídeos em combustíveis, materiais poliméricos e insumos químicos: algumas aplicações da catálise na oleoquímica. Química Nova, [s.l.], v. 30, n. 3, p.667-676, jun. 2007. FapUNIFESP (SciELO).

8. CHAVANNE, G. BE pat. 422,877 1937. CA 1938, 32, 4313, 1938.

9. SUAREZ, P. A. Z. et al. 70ํaniversário do biodiesel em 2007: evolução histórica e situação atual no brasil. Química Nova, [s.I.], v. 30, n. 8, p.2068-2071, 2007. FapUNIFESP (SciELO).

10. Programa Nacional de Produção e uso do Biodiesel. Disponível em: <http://www.mme.gov.br/programas/biodiesel/menu/biodiesel/pnpb.html>. Acesso em: 24 de Maio de 2016.

11. DEMIRBAS, A. et al. Comparison of transesterification methods for production of biodiesel from vegetable oils and fats. Energy Conversion And Management, [s.l.], v. 49, n. 1, p.125-130, jan. 2008. Elsevier BV.

12. Carvalho, M. S.; Hidrogenação seletiva do biodiesel de soja em sistema bifásico utilizando o líquido iônico BMI.BF4; Dissertação de Mestrado, Universidade de Brasília, Brasil 2008.

13. MORETTO, E. Tecnologia de óleos e gorduras vegetais na indústria de alimentos. Varela, 1998. 
14. CAREY, F. A. Organic chemistry. 2000. 4Th ed McGrall-Hill, Inc ; Washington 2000, p. 221.

15. Agência Nacional Do Petróleo, Gás Natural E Biocombustíveis Resolução ANP № 45, de 25.8.2014 - DOU 26.8.2014 Disponível em: http://nxt.anp.gov.br/nxt/gateway.dll//eg/resolucoes_anp/2014/agosto/ranp\%2045\%20 -\%202014.xml. Acesso em 10 de Maio de 2015.

16. Boletins ANP; Fevereiro de 2015; Disponível em: www.anp.gov.br/?dw=74334 Acesso em 25 de Março de 2016.

17. A Soja no Brasil Disponível em: http://www.cnpso.embrapa.br/producaosoja/SojanoBrasil.htm Acesso em: 25 de Março de 2016.

18. Governo cogita mais de $10 \%$ de biodiesel no diesel Disponível em: http://www.canalrural.com.br/noticias/rural-noticias/governo-cogita-mais-biodieseldiesel-55605 Acesso em 25 de Março de 2016

19. Produção Nacional de Biodiesel Puro - B100 (metros cúbicos) Disponível em: www.anp.gov.br/?dw=8740 Acesso em: 25 de março 2016.

20. SOUZA, Bruno S. et al. Selective partial biodiesel hydrogenation using highly active supported palladium nanoparticles in imidazolium-based ionic liquid. Applied Catalysis A: General, [s.I.], v. 433-434, p.109-114, ago. 2012. Elsevier BV.

21. CARVALHO, Myller $S$. et al. In situ generated palladium nanoparticles in imidazolium-based ionic liquids: a versatile medium for an efficient and selective partial biodiesel hydrogenation. Catal. Sci. Technol., [s.I.], v. 1, n. 3, p.480-488, 2011. Royal Society of Chemistry (RSC).

22. PINHO, David MM; SUAREZ, Paulo AZ. A Hidrogenação de óleos e gorduras e suas aplicações industriais. Revista Virtual de Química, v. 5, n. 1, p. 47-62, 2013.

23. BOURIAZOS, Achilleas et al. Catalytic Conversions in Aqueous Media. Part 2. A Novel and Highly Efficient Biphasic Hydrogenation of Renewable Methyl Esters of Linseed and Sunflower Oils to High Quality Biodiesel Employing Rh/TPPTS Complexes. Catalysis Letters, [s.I.], v. 121, n. 1-2, p.158-164, 3 nov. 2007. Springer Science + Business Media.

24. GRAU, Ricardo J.; CASSANO, Alberto E.; BALTANÁS, Miguel A.. Catalysts and Network Modeling in Vegetable Oil Hydrogenation Processes. Catalysis Reviews, [s.I.], v. 30, n. 1, p.1-48, fev. 1988. Informa UK Limited.

25. ZAJCEW, Mykola. The hydrogenation of fatty oils with palladium catalyst. I. Hydrogenation of castor oil. J Am Oil Chem Soc, [s.I.], v. 35, n. 9, p.475-477, set. 1958. Springer Science + Business Media.

26. RODRIGUES, J. P. et al. Comparing Thermal-Cracking and Catalytic Hydrocracking in the Presence of $\mathrm{Rh}$ and Ru Catalysts to Produce Liquid Hydrocarbons from 
Vegetable Oils. Journal Of The Brazilian Chemical Society, [s.I.], p.2364-2369, 2014. GN1 Genesis Network.

27. DIJKSTRA, Albert J.. Revisiting the formation of trans isomers during partial hydrogenation of triacylglycerol oils. European Journal Of Lipid Science And Technology, [s.I.], v. 108, n. 3, p.249-264, mar. 2006. Wiley-Blackwell.

28. $\mathrm{HU}$, Chaoquan et al. Catalytic hydrogenation of $\mathrm{C}=\mathrm{C}$ and $\mathrm{C}=\mathrm{O}$ in unsaturated fatty acid methyl esters. Catal. Sci. Technol., [s.I.], v. 4, n. 8, p.2427-2444, 2014. Royal Society of Chemistry (RSC).

29. Nickel in Drinking-water World Health Organization, Disponível em: http://www.who.int/water_sanitation_health/gdwqrevision/nickel2005.pdf Acesso em: 27 de Março de 2016

30. Hastert, R.C. Hydrogentation: quo vadis? SCI lecture papers series. ISSN 1353-114X.

31. Pinho, D. M. M.; Blendas de biodiesel: Dificuldade do mercado de combustíveis e possíveis soluções; Dissertação de mestrado, Universidade de Brasília, Brasil, 2013.

32. Cedeno F. O.; Prieto M. M.; Espina A.; Garcia J. R. Measurements of Temperature and melting heat of some pure fatty acids and their binary and ternary mixtures by differential scanning calorimetry. Thermochimica Acta, vol. 369, n. 1-2, p. 39-50, 2001.

33. RAMALHO, H. F.; SUAREZ, P. A. Z.. The Chemistry of Oils and Fats and their Extraction and Refining Processes. Revista Virtual de Química, [s.l.], v. 5, n. 1, p.2-15, 2013. GN1 Genesis Network.

34. JACINTO, Marcos J. et al. Recoverable rhodium nanoparticles: Synthesis, characterization and catalytic performance in hydrogenation reactions. Applied Catalysis A: General, [s.l.], v. 338, n. 1-2, p.52-57, abr. 2008. Elsevier BV.

35. ATABAEV, Timur $S h$ et al. Mesoporous silica with fibrous morphology: a multifunctional core-shell platform for biomedical applications. Nanotechnology, [s.l.], v. 24, n. 34, p.345603-345609, 30 jul. 2013. IOP Publishing.

36. SUAREZ, Paulo A.z. et al. The use of new ionic liquids in two-phase catalytic hydrogenation reaction by rhodium complexes. Polyhedron, [s.l.], v. 15, n. 7, p.12171219, abr. 1996. Elsevier BV.

37. CONSORTI, Crestina S. et al. Líquidos iônicos contendo o cátion dialquilimidazólio: estrutura, propriedades físico-químicas e comportamento em solução. Química Nova, [s.I.], v. 24, n. 6, p.830-837, dez. 2001. FapUNIFESP (SciELO).

38. WILKES, John S. et al. Dialkylimidazolium chloroaluminate melts: a new class of room-temperature ionic liquids for electrochemistry, spectroscopy and synthesis. Inorganic Chemistry, [s.I.], v. 21, n. 3, p.1263-1264, mar. 1982. American Chemical Society (ACS). 
39. SUAREZ, Paulo A. Z. et al. Electrochemical Behavior of Vitreous Glass Carbon and Platinum Electrodes in the lonic Liquid 1-n-Butyl-3-Methylimidazolium Trifluoroacetate. J. Braz. Chem. Soc., [s.I.], v. 13, n. 1, p.106-109, fev. 2002. FapUNIFESP (SciELO).

40. SUAREZ, P. A. Z. et al. Synthesis and physical-chemical properties of ionic liquids based on 1-n-butyl-3-methylimidazolium cation. Journal de Chimie Physique Et de Physico-chimie Biologique, [s.I.], v. 95, n. 7, p.1626-1639, jul. 1998. EDP Sciences.

41. DUPONT, J.; SUAREZ, P. A. Z. Physico-chemical processes in imidazolium ionic liquids. Phys. Chem. Chem. Phys., [s.I.], v. 8, n. 21, p.2441-2452, 2006. Royal Society of Chemistry (RSC).

42. OLIVIER-BOURBIGOU, Hélène; MAGNA, Lionel. Ionic liquids: perspectives for organic and catalytic reactions. Journal Of Molecular Catalysis A: Chemical, [s.I.], v. 182-183, p.419-437, maio 2002. Elsevier BV.

43. SUAREZ P. A. Z.; RAMALHO, H. F. On the Use of lonic Liquids in Biomass Transformations: Reaction Media and Catalysts. Current Organic Chemistry, v. 17, n. 3, p. 229-237, 2013.

44. SCHOLTEN, J. D.; Leal, B. C.; DUPONT, J. Transition Metal Nanoparticle Catalysis in Ionic Liquids. Acs Catal., [s.I.], v. 2, n. 1, p.184-200, jan. 2012. American Chemical Society (ACS).

45. GATES, B. C. Catalytic Chemistry, John Wiley \& Sons. Inc., New York, p. 386-392, 1992.

46. Clayden, J.; Greeves, N.; Warren, S.; Wothers, P.; Organic Chemistry; Oxford University Press: New York, 2001.

47. JACINTO, M. J. et al. Platinum-supported mesoporous silica of facile recovery as a catalyst for hydrogenation of polyaromatic hydrocarbons under ultra-mild conditions. J Sol-gel Sci Technol, [s.I.], v. 77, n. 2, p.298-305, 2 set. 2015. Springer Science + Business Media.

48. CASSOL, Claúdia C. et al. A Simple and Practical Method for the Preparation and Purity Determination of Halide-Free Imidazolium lonic Liquids. Advanced Synthesis \& Catalysis, [s.I.], v. 348, n. 1-2, p.243-248, jan. 2006. Wiley-Blackwell.

49. CARVALHO, Myller S. et al. Chromatographic analyses of fatty acid methyl esters by HPLC-UV and GC-FID. J. Braz. Chem. Soc., [s.I.], v. 23, n. 4, p.763-769, abr. 2012. FapUNIFESP (SciELO).

50. 109602 Methyl stearate Disponível em: http://www.emdmillipore.com/CA/en/product/Methyl-stearate,MDA_CHEM109602?bd=1 Acesso em: 18/05/2016

51.

Methyl

oleate

Disponível em: http://www.sigmaaldrich.com/catalog/product/aldrich/311111 ?lang=pt\&region=BR Acesso em: 18/05/2016 
52.

Methyl

linoleate

Disponível

em:

http://www.sigmaaldrich.com/catalog/product/sigma/l1876?lang=pt\&region=BR

Acesso em: 18/05/2016

53.

Methyl

linolenate

Disponível

em:

http://www.sigmaaldrich.com/catalog/product/sigma/l2626?lang=pt\&region=BR\&cm_s p=Insite-_-prodRecCold_xviews-_-prodRecCold10-8 Acesso em: 18/05/2016 
ANEXOS 


\section{Anexos}

\subsection{Limite de detecção (LD) e desvio padrão obtido pela curva analítica (SD) ${ }^{12}$}

O limite de detecção para as análisesde CLAE-UV foram determinados anteriormente por Myller S. Carvalho, 2008 e podem ser conferidos na tabela a seguir.

Tabela 17: Limites de detecção para os principais ésteres metílicos na composição do biodiesel se soja. ${ }^{12}$

\begin{tabular}{ccc}
\hline EMAG & SD $^{\mathrm{a}}$ & $\mathrm{LD}^{\mathrm{b}}$ \\
\hline $18: 3$ & $1,15 \times 10^{-6}$ & $3,44 \times 10^{-6}$ \\
$18: 2$ & $1,23 \times 10^{-6}$ & $3,68 \times 10^{-6}$ \\
$18: 1$ cis & $0,39 \times 10^{-4}$ & $1,17 \times 10^{-4}$ \\
$16: 0$ & $0,37 \times 10^{-3}$ & $1,01 \times 10^{-3}$ \\
$18: 1$ trans & $2,47 \times 10^{-5}$ & $7,42 \times 10^{-5}$ \\
$18: 0$ & $0,51 \times 10^{-4}$ & $1,53 \times 10^{-4}$
\end{tabular}

a) Desvio padrão obtido na curva de calibração. b) Limite de detecção do método expresso em $\mathrm{g}$ de EMAG por $g$ de $\mathrm{H}_{3} \mathrm{CCN}$. $\mathrm{LD}=3 \times \mathrm{SD}$

\subsection{Precisão e exatidão do método ${ }^{12}$}

A precisão do método empregado pode ser conferida na tabela 18

Tabela 18: Precisão do método de análise de ésteres metílicos. ${ }^{12}$

\begin{tabular}{cccc}
\hline EMAG & Média $^{\text {a }}$ & D.P. $^{\text {b }}$ & D.P.R $^{\text {c }}(\%)$ \\
\hline $18: 3$ & 2,88 & $\pm 0,054$ & 1,91 \\
$18: 2$ & 45,00 & $\pm 0,460$ & 1,01 \\
$18: 1$ cis & 30,97 & $\pm 0,370$ & 1,19 \\
$16: 0$ & 16,73 & $\pm 0,044$ & 0,26 \\
$18: 1$ trans & 5,72 & $\pm 0,073$ & 2,32 \\
$18: 0$ & 3,83 & $\pm 0,088$ & 1,91
\end{tabular}

a) Média das porcentagens obtidas em 5 corridas do produto da reação 23; b) Desvio padrão das medidas; c) Desvio padrão relativo $=100$ (D.P.) $(\text { Média })^{-1}$ 
A exatidão do método foi determinada pela porcentagem de recuperação dos EMAGs. Os resultados podem ser conferidos na tabela 19.

Tabela 19: Exatidão do método de determinação de EMAGs por CLAE-UV. ${ }^{12}$

\begin{tabular}{cccc}
\hline EMAG & Concentração esperada $^{\mathrm{a}}$ & Concentração encontrada $^{\mathrm{b}}$ & $\mathrm{R}^{\mathrm{c}}(\%)$ \\
\hline $18: 3$ & $6,20 \times 10^{-4}$ & $6,38 \times 10^{-4}$ & 102,90 \\
$18: 2$ & $4,70 \times 10^{-3}$ & $4,42 \times 10^{-3}$ & 94,04 \\
$18: 1$ cis & $3,50 \times 10^{-3}$ & $3,54 \times 10^{-3}$ & 101,14 \\
$16: 0$ & $3,90 \times 10^{-2}$ & $3,91 \times 10^{-2}$ & 100,25 \\
$18: 1$ trans & $1,15 \times 10^{-3}$ & $1,27 \times 10^{-3}$ & 112,30 \\
$18: 0$ & $8,60 \times 10^{-4}$ & $8,47 \times 10^{-4}$ & 98,49
\end{tabular}

a) Concentração calculada com a massa de padrão e solvente; b) Concentração encontrada pelo cromatograma e curva de calibração; c) Porcentagem de recuperação (R) = 100x(concentração encontrada) (concentração esperada) $)^{-1}$

\subsection{Imagem de MEV do Catalisador $\mathrm{Fe}_{3} \mathrm{O}_{4} @ \mathrm{mSiO}_{2} @ \mathrm{Pt}$}

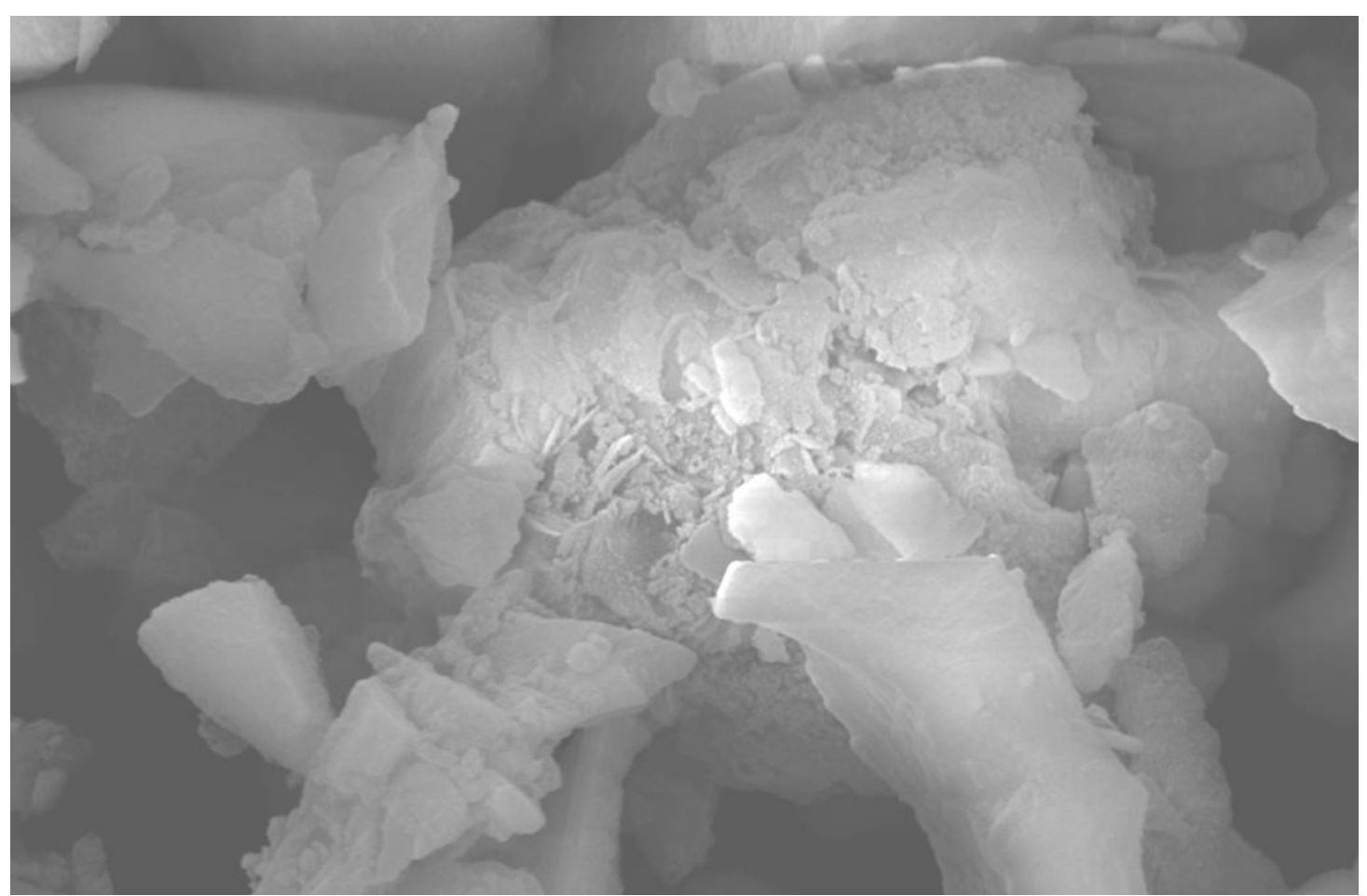

Figura 18: MEV do catalisador $\mathrm{Fe}_{3} \mathrm{O}_{4} @ \mathrm{mSiO}_{2} @ P t$. Aumento de 3.000 x. 